OPEN ACCESS

Edited by:

Yu Lung Lau,

The University of Hong Kong,

Hong Kong

Reviewed by:

Fulvio Mavilio,

University of Modena and Reggio

Emilia, Italy

Andrew R. Gennery,

Newcastle University, United Kingdom

Alain Fischer,

Institut National de la Santé et de la

Recherche Médicale (INSERM),

France

*Correspondence:

Adrian James Thrasher

a.thrasher@ucl.ac.uk

Specialty section:

This article was submitted to

Primary Immunodeficiencies,

a section of the journal

Frontiers in Immunology

Received: 21 September 2020 Accepted: 02 November 2020

Published: 27 November 2020

Citation:

Blanco E, Izotova N, Booth C and

Thrasher AJ (2020) Immune

Reconstitution After Gene

Therapy Approaches in Patients

With X-Linked Severe Combined

Immunodeficiency Disease.

Front. Immunol. 11:608653.

doi: 10.3389/fimmu.2020.608653

\section{Immune Reconstitution After Gene Therapy Approaches in Patients With X-Linked Severe Combined Immunodeficiency Disease}

\author{
Elena Blanco ${ }^{1}$, Natalia Izotova ${ }^{1}$, Claire Booth ${ }^{1,2}$ and Adrian James Thrasher ${ }^{1,2^{*}}$ \\ ${ }^{1}$ Molecular and Cellular Immunology, Great Ormond Street Institute of Child Health, University College London, London, \\ United Kingdom, ${ }^{2}$ Department of Paediatric Immunology, Great Ormond Street Hospital NHS Trust, London, United Kingdom
}

X-linked severe immunodeficiency disease (SCID-X1) is an inherited, rare, and lifethreating disease. The genetic origin is a defect in the interleukin 2 receptor $\gamma$ chain (IL2RG) gene and patients are classically characterized by absence of $\mathrm{T}$ and NK cells, as well as presence of partially-functional B cells. Without any treatment the disease is usually lethal during the first year of life. The treatment of choice for these patients is hematopoietic stem cell transplantation, with an excellent survival rate $(>90 \%)$ if an HLA-matched sibling donor is available. However, when alternative donors are used, the success and survival rates are often lower. Gene therapy has been developed as an alternative treatment initially using $\gamma$-retroviral vectors to correct the defective $\gamma$ chain in the absence of pre-conditioning treatment. The results were highly promising in SCID-X1 infants, showing long-term T-cell recovery and clinical benefit, although NK and B cell recovery was less robust. However, some infants developed T-cell acute lymphoblastic leukemia after the gene therapy, due to vector-mediated insertional mutagenesis. Consequently, considerable efforts have been made to develop safer vectors. The most recent clinical trials using lentiviral vectors together with a low-dose pre-conditioning regimen have demonstrated excellent sustained T cell recovery, but also B and NK cells, in both children and adults. This review provides an overview about the different gene therapy approaches used over the last 20 years to treat SCID-X1 patients, particularly focusing on lymphoid immune reconstitution, as well as the developments that have improved the process and outcomes.

Keywords: X-linked severe immunodeficiency disease, gene therapy, immune reconstitution, clinical trial, $\mathrm{T}$ cells, $B$ cells, NK cells, conditioning

\section{INTRODUCTION}

Severe combined immunodeficiency diseases (SCIDs) are a group of life-threatening and rare primary immunodeficiencies, with an overall estimated incidence of $\approx 1: 50,000$ live births. SCID patients are characterized by a profound defect in the number or function of T-cells, which are associated to a variable extent with abnormalities in B and NK cell populations. These immune 
alterations are caused by a monogenic defect, with up to eighteen different genes identified so far (1). The most common form of SCID in Western geographies is X-linked SCID (SCID-X1), which accounts for $\approx 25-40 \%$ of all diagnosed SCIDs $(2,3)$. Due to severe immune defects and the ensuing occurrence of lifethreatening infections, SCID-X1 is usually lethal in the first year of life unless definitive immune reconstitution is achieved. Nowadays there are two possible therapeutic approaches for the restoration of the immune system in SCID-X1 patients: 1) hematopoietic stem cell transplantation (HSCT); and 2) autologous gene therapy (4).

Gene therapy employs the introduction of DNA or RNA into target cells by adding a correct version of the gene (additive gene therapy) or more precisely correcting the defective gene or targeting the transgene to desirable genomic sites (gene editing) (5). Gene therapy used for SCID-X1 clinical trials so far has been based on the use of retroviral vectors to transfer a corrective copy of the defective gene to autologous hematopoietic stem and progenitor cells (HSPCs), and was successfully performed for the first time more than 20 years ago (6). However, the outstanding results observed regarding the clinical benefit and the T-cell reconstitution were tempered by the occurrence of leukemogenesis in some patients (7). With the development of safer vectors as well as the introduction of lowdose conditioning regimens, new clinical trials are currently being performed to confirm the safety and effectiveness of these therapeutic approaches. Here, we review the main characteristics of SCID-X1 and the available treatments, especially focusing on the technical aspects of gene therapy approaches used over time, and the resultant immunological reconstitution of $\mathrm{T}, \mathrm{B}$, and NK cells.

\section{PHYSIOPATHOLOGY OF SCID-X1}

The genetic origin of SCID-X1 was identified in 1993 due to the presence of mutations in the interleukin 2 receptor $\gamma$ chain $(I L 2 R G)$ gene $(8,9)$. This gene is located on Xq13.1 locus thus has an X-linked inherited pattern and all patients are males (10). The IL2RG gene contains eight exons and more than 200 unique mutations have been identified so far (11). Around one half of mutations are missense and nonsense, while the remaining half are insertion/deletions or splicing mutations (11).

The IL2RG encodes the common cytokine receptor $\gamma$ chain $(\gamma c)$, which is part of the receptor for a number of cytokines, including IL-2, IL-4, IL-7, IL-9, IL-15, and IL-21 (12). Due to the critical role of IL-7 and IL-15 in T-cell and NK-cell maturation, respectively (13), SCID-X1 patients are typically characterized by the absence of $\mathrm{T}$ cells and NK cells. In addition, despite the normal or even elevated number of B cells observed in SCID-X1 patients, these are only partially functional, most likely due to the defective signaling of IL-4 and especially IL-21 (14). Accordingly, these patients classically present with defects in both humoral and cellular compartments of the immune system, and a T-B $+\mathrm{NK}$ - phenotype (15). Without a curative treatment, patients usually succumb early in life to viral and opportunistic infections
(4, 10). Nonetheless, some forms of atypical SCID-X1 with milder phenotypes have been identified, most of them caused by hypomorphic mutations $(11,16)$ and others as a result of partially corrective somatic reversions (17-21).

The early treatment of patients, achieved through earlier diagnosis, is associated with a better outcome (2). Thus, neonatal screening for SCID based on the $\mathrm{T}$ cell receptor excision circle (TREC) assay is being applied in many countries worldwide either as pilot studies or incorporated into routine healthcare $(2,22)$. The identification of reduced or absent TRECs can also be caused by non-SCID diseases (2), so this finding must be followed by lymphocyte immunophenotyping and further diagnostic investigations $(23,24)$ to help orientate the genetic studies (15). Due to the presence of maternal T-cells or leaky production of oligoclonal cells, total T-cell numbers might initially be significant, so the analysis of subpopulations including naïve T-cells and recent thymic emigrants (RTE) is crucial $(23,25)$. The final diagnosis of SCID-X1 is established by the identification of pathogenic variants in the IL $2 R G$ gene, although sometimes this requires confirmation by other studies, such as functional assays, especially in atypical SCID$\mathrm{X} 1$ (26). The expression of $\gamma_{c}$ is not conclusive, as it can be normal (but nonfunctional) in some patients (10).

\section{TREATMENT APPROACHES}

Following a diagnosis of SCID-X1, therapeutic measures must be applied as soon as possible, including transfer to a specialized center, establishment of immunoglobulin replacement therapy (IgRT) and appropriate antimicrobial prophylaxis (15, 27-30). HSCT or gene therapy should be performed as soon as possible to restore immunity, for instance adhering to the consensus guidelines proposed by the European Society for Blood and Marrow Transplantation and the European Society for Immunodeficiencies (EBMT/ESID) (31) or USIDnet advice.

\section{Hematopoietic Stem Cell Transplantation}

Since the first SCID-X1 patient was successfully treated with HSCT in 1968 (32), this approach has been the treatment of choice for many forms of PID (33). Despite a relatively high number of reports showing the results obtained after HSCT in SCID patients, and differences in the survival and immune recovery according to the SCID subtype $(34,35)$, very few studies focused specifically on SCID-X1 $(36,37)$. Overall survival of SCID patients after HSCT is $>70 \%(34,35,38)$, although several factors may have an impact, such as donor matching, older age, presence of infection, SCID phenotype/ genotype and ethnicity $(34,35,38,39)$. Use of geno-identical matched sibling donors (MSDs) results in the highest survival rates $(>90 \%)(34,35,38,40,41)$. However, because MSDs are available for less than $20 \%$ of SCID patients, alternative donors including mismatched related donors, matched unrelated donors or umbilical-cord blood donors are often used, with lower overall survival rates $(\approx 60-75 \%)(34,35,38,41)$. Overall survival rates using these alternative donors have however increased 
considerably over the years, most likely due to the improvement in HLA-typing techniques as well as the use of treatments to abrogate complications such as graft versus host disease (GvHD) $(42,43)$. Accordingly, T-cell and B-cell reconstitution is usually superior in patients treated with MSDs vs. other donors (38). Independent of the type of donor used, HSCT performed in patients with age $<3.5$ months is associated with a higher survival and reduced rate of clinical problems $(38,39)$. On the other hand, the presence of active infection is associated with reduced survival (38). Other complications that affect post-HSCT outcomes include acute and chronic GvHD, graft failure requiring a second transplant, and late effects of conditioning regimens $(34,38)$.

Immune reconstitution after HSCT is usually achieved in the T cell compartment after 3-4 months, normalizing after 9-12 months (43). The numbers of $\mathrm{CD}^{+}$and $\mathrm{CD} 4^{+} \mathrm{CD} 45 \mathrm{RA}^{+}$naïve $\mathrm{T}$ cells early after HSCT are predictive of long-term reconstitution and overall survival $(34,44)$. In contrast, B-cell immune recovery is more variable, with $43 \%-66 \%$ of SCID-X1 being dependent on $\operatorname{IgRT}(36,39,41,45)$, which has been recently associated with a poorer quality of life in these patients (36). The lack of B-cell functional recovery observed in SCID-X1 patients despite successful T-cell reconstitution is likely due to a failure in the signaling through IL-21 in B-cells (14) and is associated with a reduced donor B-cell engraftment particularly in unconditioned procedures (38, 45-48). Nevertheless, a recent study reported an ongoing B-cell response with intact host B-cell signaling through IL-21 in a SCID-X1 patient 47 years after the HSCT, although this is most likely due to a hypomorphic $\gamma c$ variant (49).

Reduced B-cell engraftment and reconstitution in SCID-X1 patients might be explained by the occupation of niches by host $\mathrm{B}$-cell precursors, as in these patients the B-cell maturation in bone marrow (BM) is unaffected (50). Therefore, the use of pretransplantation conditioning (typically alkylating agents such as busulfan) has been applied in several centers (46). On the one hand, it is clear that pre-conditioning treatment is associated with a lower risk of treatment failure and more reliable B-cell reconstitution, which is associated with a better outcome (34, 38). However, some authors claim that this approach is not a guarantee for recovery of B-cell function, since there are cases without conditioning that maintain B-cell chimerism, as well as patients with pre-conditioning that still need IgRT after HSCT $(46,51)$. In addition, some studies suggested a relationship between the use of conditioning and reduced survival (51), even though this has not been universally observed in other multicenter studies $(34,35)$, as well as a potential risk of GvHD (34). Similarly to B cell recovery, successful NK cell reconstitution has been associated with pre-conditioning treatment (52).

In conclusion, pre-conditioning seems to improve B-cell chimerism and immune reconstitution in SCID-X1 patients after HSCT $(34,36,37,53)$, although more studies are needed to determine the ideal regimen balancing efficacy with toxicity, particularly in young infants (54). In line with this, the possible use of targeted biologic agents for stem cell depletion (e.g. monoclonal antibodies such as anti-CD117 or anti-CD45) is very promising (55-57).

\section{Gene Therapy}

Despite the undoubted benefit of HSCT in the treatment of SCID$\mathrm{X} 1$, the difficulties to find a suitable donor, lower survival rates in the absence of MSD, lifelong use of IgRT in a relatively high number of cases, as well as the occurrence of adverse effects like GvHD and graft failure/rejection have driven the development of autologous gene therapy as an alternative curative treatment. In SCID-X1 patients, all the procedures clinically used so far consist of ex vivo introduction of a corrective copy of the IL2RG gene using viral vectors in autologous HSPCs $(6,58-64)$. In brief, CD34 ${ }^{+}$HSPCs are obtained from $\mathrm{BM}$ or mobilized peripheral blood stem cells and cultured and transduced under conditions that enhance permissiveness to gene transfer. Finally, the corrected cells are reintroduced in the patients, either with (in latter studies) or without any kind of prior conditioning. A schematic representation of gene therapy protocol used in SCID-X1 patients is shown in Figure 1.

Gene therapy is particularly attractive in the case of SCID-X1, due to the powerful survival and growth advantage of $\gamma_{c}$ corrected precursors (65). This is in line with the partial but sustained immune reconstitution of T-cells observed in SCID-X1 patients with spontaneous revertant mutations in their precursor cells $(18-21,66,67)$. In general, these reversions are limited to the T-cell compartment $(18,19,21)$, despite some exceptions that have been recently described $(20,66,67)$. Hsu et al. reported a patient with a reversion observed in $\mathrm{T}$ cells and also in $\mathrm{B}$ cells, although only $\approx 1 \%$ of $B$ cells expressed $\gamma_{c}$ and this was not enough to correct the antibody deficiency (20). This reduced percentage might be the result of the lack of (or reduced) advantage for corrected B-cell precursors due to the redundant role of $\gamma_{c}$ in antigen-independent B-cell maturation, though this is indispensable for its function $(14,68)$. Furthermore, Okuno et al. reported another patient with a probable reversion, detected in several lymphoid subsets, showing the highest percentages of reversion in $\mathrm{CD}^{+}$T-cells (19\%) and NK cells (31\%). Thus, authors suggest that the correction might have occurred in a common T/NK precursor and these cytotoxic cells would have a growth advantage (66).

Gene therapy was first implemented in SCID-X1 patients because of the encouraging results obtained in in vitro studies (69-71) and animal models (72) by IL2RG gene transfer using gammaretroviral vectors $(\gamma \mathrm{RV})$. The first gene therapy clinical trial in patients with SCID-X1 began at Necker Hospital (Paris, France) in $1999(6,58)$, followed soon after by another clinical trial carried out at Great Ormond Street Hospital (GOSH, London, UK) (59). The inclusion criteria for these trials included confirmed mutation in IL2RG gene and the absence of an HLA-identical donor $(58,59)$. Patients age ranged between 1 and 46 months $(73,74)$. Both studies used a first-generation Moloney murine leukemia virus vector expressing the $\gamma_{c}$ complementary DNA, and the transgene expression was regulated by endogenous viral long terminal repeat (LTR) sequences. A schematic representation of vectors is shown in 


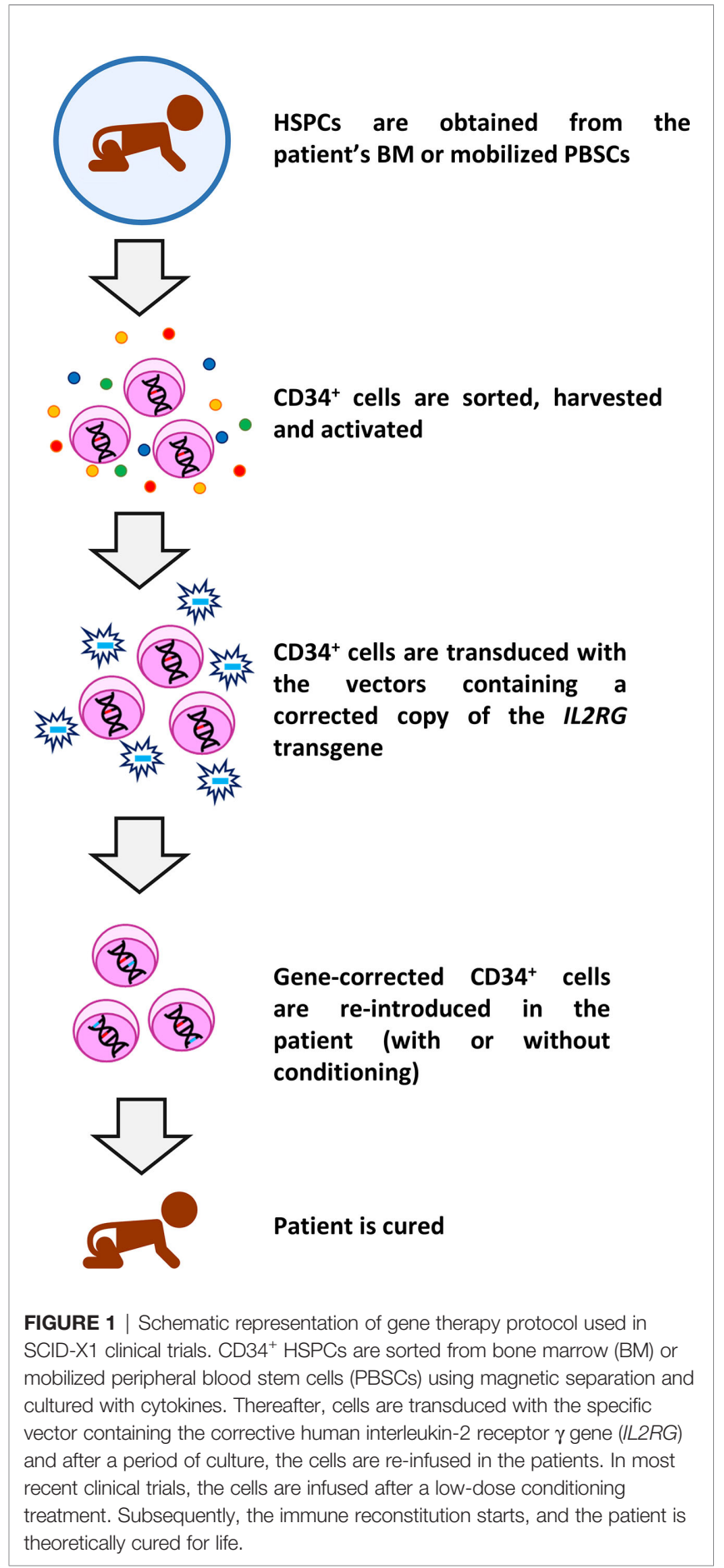

Figure 2A. $\gamma \mathrm{RV}$ s were chosen because these were the first retroviruses applied to hematopoietic cell gene transfer, and a random integration pattern was expected (75). Both studies followed the same protocol, with some differences in vector pseudotyping and culture conditions (59). Corrected cells were introduced in the patients without any kind of previous conditioning $(6,58,59)$.

The results were exceptional, with most patients showing good long-term immune reconstitution (discussed below) and an

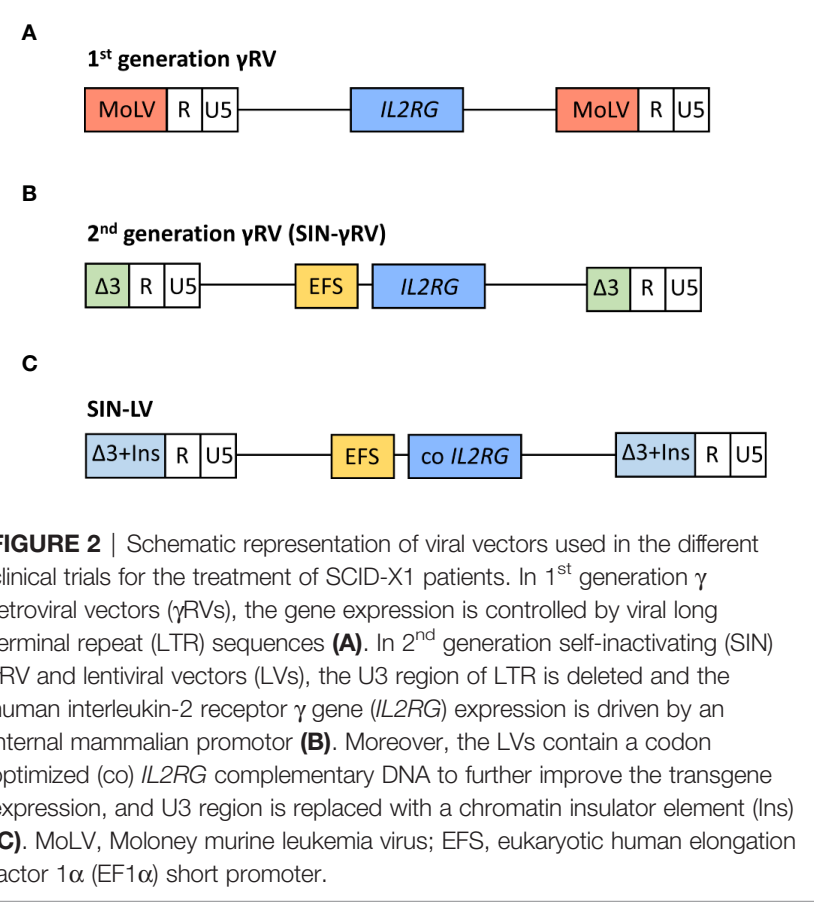

overall survival of $90 \%(18 / 20)$ (taking both clinical trials together) $(73,74)$. However, unexpectedly six patients developed T-cell acute lymphoblastic leukemia (T-ALL) 2-14 years after the treatment (five in Paris and one in London), being fatal for one patient $(7,76-78)$. All the other patients responded well to the chemotherapy treatment. Interestingly, T-cell reconstitution substantially recovered after chemotherapy without the immediate need for a further autologous or allogeneic graft $(73,74)$. The origin of this effect was insertional mutagenesis, due to the integration of the vector near proto-oncogenes (mainly LMO-2) and their transcriptional activation by the viral LTR enhancer sequences $(76,77,79)$. In addition, the presence of other multiple genetic aberrations suggests that the insertional mutagenesis was the first event and was followed by other hits that contributed to the malignant transformation $(76,77)$. At first, aberrant $\gamma_{\mathrm{c}}$ signaling was thought to contribute to leukemogenesis (79), which would be in line with the absence of clonal proliferation in adenosine deaminase (ADA) deficiency SCID (ADA-SCID) patients $(80,81)$, despite similar integration pattern near LMO2 and other proto-oncogenes in these patients (82). However, neither $\gamma_{c}$ overexpression nor constitutive activation of JAK3 was observed in the leukemic cells of SCID-X1 patients $(76,79)$. Despite these results, the correction of $I L 2 R G$ was suggested as a contributor itself to cancer development, based on murine models $(83,84)$. However, this hypothesis is controversial and several papers have strongly argued against this concept (85-87) [Pike-Overzet et al. (65) reviewed exhaustively the main findings regarding this issue], and it is now commonly accepted that $I L 2 R G$ does not have an inherent oncogenic role although it is clearly permissive to $\mathrm{T}$ cell development. Accordingly, a recent study using transgenic mice showed that IL2RG was not directly 
oncogenic, although an accelerated leukemogenesis was observed in the thymus due to the functional cooperation between LMO2 and $I L 2 R G$ (88), indicating that IL2RG might have a cooperative role. Self-renewal of thymocytes induced by the limiting thymic precursor supply from BM has been also suggested as another contributor to T-ALL in these patients $(89,90)$, as in these subjects $\mathrm{T}$-cell production is maintained in the absence of corrected precursors in BM (73). However, these studies are based on murine models and do not appear to be supported by clinical experience in unconditioned allogeneic HSCT where leukemogenesis has not been observed (91). In conclusion, the leukemogenesis observed in some SCID-X1 patients treated with gene therapy predominantly originates from insertional mutagenesis associated with the $\gamma \mathrm{RV}$, which (contrary to the previous belief) do not have a random integration pattern (92). Detailed insertion site analysis has demonstrated a preferential integration in transcriptionally active gene regulatory regions. This favored target site profile has its origin in the interaction between the virus integrase and the bromodomain and extraterminal domain proteins (BET), which also interact with histone acetyl modifications in active enhancers and promotors (93-95). Therefore, these vectors preferentially target active genes, and can cause gene expression dysregulation induced by endogenous proviral promotor and enhancer sequences located in the proviral LTRs. Subsequently, leukemogenesis has also been observed in patients with Wiskott-Aldrich syndrome (96) and chronic granulomatous disease (97) treated with similar vector configurations. In contrast, despite the use of $\gamma \mathrm{RVs}$ for gene therapy of ADA-SCID and the similar vector integration profile observed (98), no malignant transformation has been reported in any of these patients so far $(80,82,99,100)$. A possible explanation for this phenomenon is that a more detoxified environment, as a consequence of the recovery of ADA function, would facilitate the maturation of non-corrected thymocytes, which might compete with transduced cells containing the deleterious mutations (90). On the other hand, the improved engraftment achieved by conditioning treatment used in ADA-SCID patients could lead to increased thymus precursor seeding from bone marrow HSPC, reducing the thymocyte replicative stress and consequently the oncogenic risk (90). Conditioning may, therefore, play an important role, not only in the efficacy of the therapy (discussed below) but also in safety.

Consequently, extensive efforts were made to develop safer vectors, reducing the insertional activation of endogenous genes but maintaining efficacy. The first approach was the design and evaluation of self-inactivating (SIN)- $\gamma R$ Vs, in which the LTR U3 regions (containing the viral promoter and enhancer sequences) were deleted, and transgene expression was controlled by internal regulatory elements $(101,102)$. Thus, a SIN- $\gamma$ RV with $I L 2 R G$ expression driven by the eukaryotic human elongation factor $1 \alpha(\mathrm{EF} 1 \alpha)$ short promoter (EFS) (Figure 2B) was used in a multicenter clinical study performed in Europe and USA (63). Enrolled patients were infants with SCID-X1 and inclusion criteria included confirmed mutation in IL2RG gene and the absence of an HLA-identical donor or the presence of therapy- resistant infection (this last criterion was mandatory for patients from France) (63). As well as in previous SCID-X1 clinical trials, corrected cells were infused in the absence of conditioning (63) (except for the final unreported patient treated who received low dose busulfan) (103). Data published in a preliminary report in 2014 (63) included nine patients $<1$ year old and the results demonstrated a similar immune recovery compared with the first clinical trials using $1^{\text {st }}$ generation $\gamma \mathrm{RVs}$ and an encouraging survival rate of $89 \%(8 / 9)$. Importantly, the integration profile analysis showed a lower frequency of integration sites near cancer-associated genes in this second clinical trial vs. previous studies. As expected, similar integration patterns were observed for $1^{\text {st }}$ generation $\gamma \mathrm{RV}$ s and SIN- $\gamma \mathrm{RVs}(63,104)$, in line with the described preferential integration patterns mediated by the viral integrase (93-95). Differences in overall profile therefore most likely result from in vivo selection of clones containing insertions near growth-promoting genes mediated by the enhancer sequences located in the LTR (63). Accordingly, after a median follow-up of 7.9 years (2.7-9.3 years), none of the SCID-X1 patients treated with SIN- $\gamma \mathrm{RV}$ s have to date developed cancer (103), so the improved safety of these vectors observed in preclinical studies $(101,102)$ is encouraging.

More recently, SIN-lentiviral vectors (SIN-LVs) have been developed, in which codon-optimized $\gamma c$ expression is driven by an internal EFS promoter element $(105,106)$ (Figure 2C), together with the use of low level conditioning $(60,62)$. LVs have advantages because they exhibit a safer integration pattern (107) and more efficient transduction of quiescent HSPCs (108). Furthermore, SIN-LVs have shown promising results regarding efficacy and safety in the treatment of other diseases $(109,110)$, as well as in SCID-X1 pre-clinical studies $(106,111,112)$. Similar to SIN- $\gamma \mathrm{RVs}$, the absence of viral promoters/enhancers likely play a major role in the increased safety. The use of low-dose preconditioning to improve engraftment and immune recovery in SCID-X1 patients was encouraged by previous gene therapy clinical trials $(80,113)$. Currently, several clinical trials using SIN-LVs together with the use of busulfan as a nonmyeloablative conditioning are being conducted (Table 1) and the preliminary results reported in both children and adults have showed very promising results with respect to immune reconstitution (see below) and safety $(60,62)$, even though longer follow-up is needed. The absence of leukemia development so far in those patients treated with SIN- $\gamma$ RVs and SIN-LVs also supports the idea of IL2RG correction did not have an oncogenic role in SCID-X1 patients treated in the first clinical trials.

\section{IMMUNE RECONSTITUTION IN SCID-X1 PATIENTS AFTER GENE THERAPY TREATMENT}

In general, immune reconstitution achieved in SCID-X1 patients treated with gene therapy has been encouraging, although some variability has been observed among the different clinical trials 
TABLE 1 | Gene therapy clinical trials recruiting patients for the treatment of SCID-X1 registered in https://clinicaltrials.gov/.

\begin{tabular}{|c|c|c|c|c|c|c|}
\hline Number & Estimated number of patients & Locations & Start date & Treatment & Age & Refs \\
\hline NCT03315078 & 13 & Bethesda & 2012 & $\begin{array}{l}\text { Vector: Lentivirus } \\
\text { Conditioning: Busulfan } \\
\text { Other drugs: Palifermin (to prevent side effects of busulfan) }\end{array}$ & $2-40 y$ & \\
\hline NCT01512888 & 28 & $\begin{array}{l}\text { San Francisco } \\
\text { Memphis, } \\
\text { Seattle }\end{array}$ & 2016 & $\begin{array}{l}\text { Vector: Lentivirus } \\
\text { Conditioning: Busulfan }\end{array}$ & $<24 \mathrm{~m}$ & (60) \\
\hline NCT03217617 & 10 & $\begin{array}{l}\text { Beijing } \\
\text { Shenzhen }\end{array}$ & 2017 & Vector: Lentivirus & $1 \mathrm{~m}-10 \mathrm{y}$ & \\
\hline NCT03601286 & 5 & London & 2018 & $\begin{array}{l}\text { Vector: Lentivirus } \\
\text { Conditioning: Busulfan }\end{array}$ & $2 \mathrm{~m}-5$ y & \\
\hline NCT03311503 & 10 & $\begin{array}{l}\text { Los Angeles } \\
\text { Boston } \\
\text { London }\end{array}$ & 2018 & $\begin{array}{l}\text { Vector: Lentivirus } \\
\text { Conditioning: Busulfan }\end{array}$ & $<5 y$ & \\
\hline
\end{tabular}

${ }^{*}$ Estimated start date. $m$, months; $y$, years.

performed so far, as well as among the patients included. In the next sections we discuss the main results obtained regarding the immune system recovery after gene therapy and the possible factors affecting, as well as the differences observed $v$ s. HSCT.

\section{T Cells}

In SCID-X1 children treated with gene therapy, T-cell recovery has been observed in the majority, independent of the vector employed $(6,58,63,73,74)$. Thus, in those patients treated with $1^{\text {st }}$ generation $\gamma \mathrm{RVs}$, T-cell recovery was observed for $19 / 20$ patients around 2-5 months, with 13/20 achieving levels of Tcells comparable to age-matched healthy donors at 6 months (58, 59). However, two patients received a subsequent HCST at 7 and 26 months after gene therapy, due to sub-optimal immune reconstitution and clinical deterioration $(58,114)$. One of these patients (114) as well as one of those that developed T-ALL died (74). The remaining 17 patients continue to be followed-up: 15/ 17 patients showed normal or near normal T-cell numbers, including $\mathrm{CD}^{+} \mathrm{T}$-cells (10/17) and $\mathrm{CD}^{+} \mathrm{T}$-cells (16/17), according to the last published report (GOSH cohort: 4.5-8.9 years; Necker cohort: 7.3-10.7 years) $(73,74)$. Strikingly, most patients from both studies showed a reduced CD4:CD8 ratio (ranging from 0.19 to 1.0 ) at the last follow-up $(73,74)$, which has been also reported in patients with IL2RG spontaneous reverse mutations (18-21). It has been hypothesized that this might be result of a skewed selection of CD8 cells in the thymus or a consequence of antigen-driven response, although the reason of this phenomenon remains elusive.

Similar results were obtained for the patients treated with $2^{\text {nd }}$ generation $\gamma$ RVs, without significant differences $v s$. previous clinical trials (63). From nine patients included in this study, seven were followed-up over 1-3.2 years (one patient died because of a pre-existing infection and the other was removed from the trial and underwent a cord blood transplant, due to the absence of marked T-cells). From these seven infants, six achieved a sustained $\mathrm{CD}^{+}, \mathrm{CD}^{+}$, and $\mathrm{CD}^{+} \mathrm{T}$ cell recovery. Regarding the SCID-X1 infants treated with LVs and low- intensity conditioning treatment, preliminary reports have shown very promising results, with rapid recovery of T-cells (including $\mathrm{CD}^{+}$and $\mathrm{CD} 8^{+}$), reaching stable and normal values around 6 months in $7 / 8$ cases (60).

Interestingly, the presence of naive T-cells in SCID-X1 patients years after the gene therapy (with normal or slightly reduced percentages in most of the cases), which correlated with the number of TRECS $(63,73,74)$, suggest ongoing T-cell production in these patients. These naïve T-cells were detected despite the lack of transduced B and myeloid cell, which indicates the absence of transduced common progenitors in BM and a persistence of longterm $\mathrm{T}$-cell progenitors instead (74), in line with the results recently reported by Izotova et al. (discussed below) (115).

Polyclonality was demonstrated in most children treated, independently of the vector employed, in both the TCRv $\beta$ family distribution and the CDR3 lengths $(60,63,73,74)$. Some patients showed a more restricted repertoire, which mirrors suboptimal immune reconstitution, especially in terms of total T-cells and naïve T-cells $(60,73)$. With regard to the functional capacity of T-cells, proliferative response to PHA, anti-CD3 or specific antigens (after immunization or infection) was recovered and maintained over time in most patients, although subnormal values were observed in some $(63,73,74)$.

Despite the overall good $\mathrm{T}$-cell immune reconstitution achieved in SCID-X1 children treated with gene therapy, some variability between patients has been observed. Numbers of $\gamma^{+}$ CD $34^{+}$cells infused seems to be an important factor that affects the immune recovery (75), since some of the patients treated with $1^{\text {st }}$ generation $\gamma$ RVs who received lower dose of corrected cells had the poorest T-cell recovery with two of them needed subsequent $\operatorname{HSCT}(73,74,114)$. In fact, taking the data from these two cohorts $(73,74)$, significant correlations between the number of $\mathrm{CD}_{34}{ }^{+} \mathrm{\gamma c}^{+}$cells infused/Kg and the percentage of naive $\mathrm{T}$-cells $\mathrm{CD}^{+}(\mathrm{P}=0.03)$ and the number of $\mathrm{T}$-cells $\mathrm{CD} 4^{+}$ $(\mathrm{P}=0.001)$ were observed at the last follow-up (Figure 3). Cavazzana et al. established an approximated minimum of $3 \times 10^{6} \mathrm{CD}^{+} 4^{+} \gamma^{+}$cells/Kg to achieve successful immune 


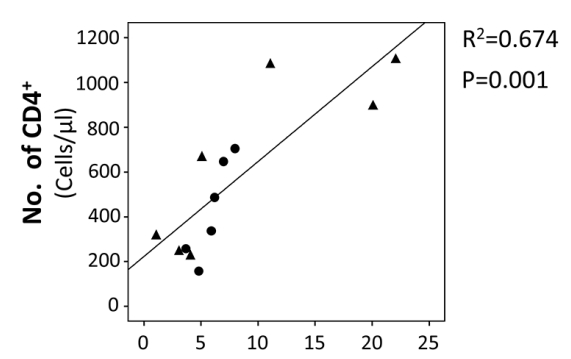

No. of $\mathrm{yc}^{+} \mathrm{CD}^{+} 4^{+}$cells infused $\times 10^{6} / \mathrm{kg}$

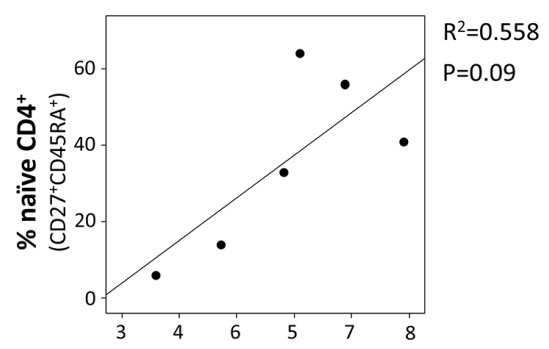

No. of $\mathrm{yc}^{+} \mathrm{CD} 34^{+}$cells infused $\times 10^{6} / \mathrm{kg}$

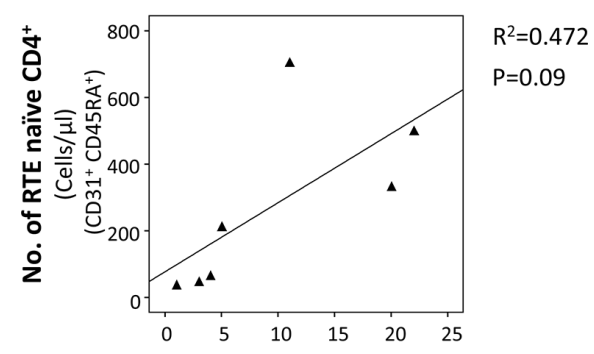

No. of $\mathrm{yc}^{+} \mathrm{CD} 34^{+}$cells infused $\times 10^{6} / \mathrm{kg}$

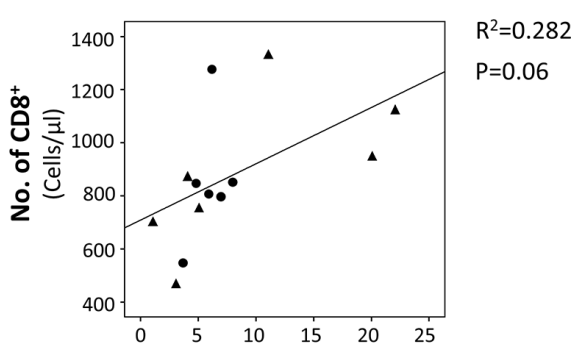

No. of $\mathrm{yc}^{+} \mathrm{CD}^{+} 4^{+}$cells infused $\times 10^{6} / \mathrm{kg}$

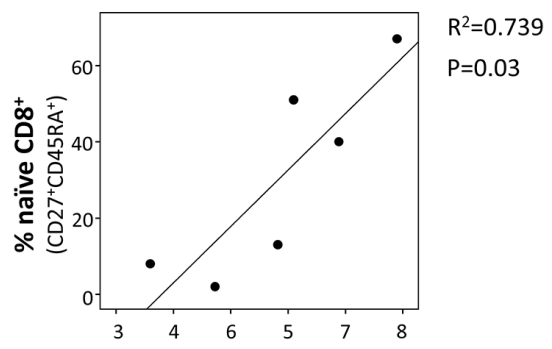

No. of $\mathrm{yc}^{+} \mathrm{CD} 34^{+}$cells infused $\times 10^{6} / \mathrm{kg}$
- GOSH cohort

A Necker cohort

FIGURE 3 | Correlation between the number of $\gamma^{+} \mathrm{CD}^{+} 4^{+}$cells infused and T-cell subsets in the last follow-up reported. Data were obtained from patients treated with the $1^{\text {st }}$ generation $\gamma$ retroviral vectors $(\gamma \mathrm{RVs})(73,74)$. When it was possible (same variables were reported or it was possible to calculate them with the information provided in the original publications), both cohorts (Necker and GOSH) were analyzed together. Correlations were determined by (squared) Pearson correlation coefficient using SPSS v18 software (IBM SPSS Statistics, IBM, Armonk, NY).

reconstitution (116). Vector copy number (VCN) in the graft was also been demonstrated to be important. In the cohort of patients treated with $2^{\text {nd }}$ generation $\gamma \mathrm{RV}$ s vectors, patients with a VCN $>0.7$ in the graft showed more reliable cell recovery (63). CD34 expression in the graft might also play a role in $\mathrm{T}$-cell reconstitution. In a recent report of SCID-X1 infants treated using LVs, two patients showed reduced expression (mean fluorescence intensity) of $\mathrm{CD}_{3} 4^{+}$in the graft prior to transduction, which was related to relatively low yields in both cases (reduced VCN and CD34 ${ }^{+}$doses). However, only one of them showed poor T-cell recovery (60).

Clinical complications at the time of gene therapy, such as hemorrhagic events (73) or viral infections (114), have been also suggested to have a role in the immune recovery. However, normal reconstitution has been observed in other SCID-X1 cases with infections at the time of gene therapy (114). The presence of active infection at the time of HSCT in SCID patients has been also related to poor T-cell recovery in some studies (38), but not in others (34).
On the other hand, in one of the treated infants in whom gene therapy failed, authors suggested that an atypical T-B+NK+ phenotype could have hampered the selective growth advantage of corrected $\mathrm{T}$-cell progenitors in $\mathrm{BM}$, hindering the T-cell recovery (114). Interestingly, a NK+ SCID phenotype has been suggested to be related with a poorer long-term $\mathrm{T}$-cell recovery after HSCT $v$. NK- (and $\mathrm{NK}^{\text {low }}$ ) phenotypes $(38,117)$. However, the presence of NK cells before the gene therapy did not seem to be an impediment for the T-cell recovery in other cases $(60,63)$, indicating the need for more systematic evaluation of this phenomenon.

Older age at the time of gene therapy is clearly associated with diminished capacity for T-cell recovery. Among SCID-X1 children treated with gene therapy, modest $\mathrm{T}$-cell reconstitution was observed in the oldest patient $(3.8$ years old) $(59,73)$, in line with results observed in other gene therapy clinical trials performed in adolescents and adults $(61,62,64)$. Thus, the results obtained in five patients with attenuated forms of SCID-X1 or previous long-term failed HSCT, and ages ranging from 10 to 20 years old treated with 
$\mathrm{BM} \mathrm{CD} 34^{+}$or GCSF-mobilized PB CD $34^{+}$transduced with $1^{\text {st }}$ generation $\gamma \mathrm{RV}$ s in the absence of conditioning, were relatively poor $(61,64)$. Limited if any T-cell reconstitution was observed in 4/5 cases (without naïve T-cells and extremely low values of TRECS) $(61,64)$. In the other case (10 years old at the time of gene therapy), a discrete increase of T-cells was observed, with presence of TRECs and recovery of proliferation capacity, but without reaching normal values for any $\mathrm{T}$-cell subset (61). Strikingly, this case had showed a transient T-cell recovery after BM transplantation. Consequently, authors suggest not only an agedependent effect, but also previous (thought temporal) thymopoiesis as an important factor for the success of gene therapy in these older patients (61). More recently, results from a clinical trial performed in five SCID-X1 patients treated with LVs and low-dose of conditioning aged between 10 and 23 years old were reported. Interestingly, those patients followed over time showed an increase in the number of marked T-cells and TRECS (62), so the combination of LVs and reduced-intensity conditioning treatment seems to achieve some T-cell reconstitution even in older patients. However, T-cell recovery was slower vs. infants treated with a similar approach (60), emphasizing the importance of more preserved thymic function.

Finally, recent reports tracking T-cells through the evaluation of vector insertional sites and TCR rearrangements in SCID-X1 patients after gene therapy has provided valuable information about immune reconstitution from gene-modified progenitors $(115,118)$. Clarke et al. estimated a minimum population of $144-$ 6,018 active progenitors in patients treated with $\gamma \mathrm{RVs}$ (follow-up: 4-180 months), with those cases who had suffered T-ALL showing smaller population sizes. Authors suggest that the occurrence of T-ALL and chemotherapy treatment might have diminished the pool size (118), which is in line with the lower number of naïve T-cells detected in one SCID-X1 patient treated with gene therapy that had suffered T-ALL (115). T-cell diversity, usage of $\mathrm{V}$ and $\mathrm{J}$ gene segments in TCR-beta and the number of unique TCR-beta CDR3 sequences were similar in healthy donors and almost all patients, despite authors suggested that a slow but gradual loss of diversity might be occurring in those patients with longer follow-up (118). Furthermore, the minimum number of divisions to generate the observed TCR-beta cell population from the precursors was estimated $\approx 9$ (118). Most recently, Izotova et al. analyzed the clonal diversity and insertional site sharing of T-cell subpopulations over the time in SCID-X1 patients treated with $1^{\text {st }}$ generation $\gamma \mathrm{RVs}$. De novo production of true (functionally and phenotypically) naïve $\mathrm{T}$ cells from long-term lymphoid progenitors (LtLP) was demonstrated up to 15 years after the loss of gene-modified HSPCs, as well as an ongoing differentiation of naïve T cells into memory/effector T-cells. T-cell production was estimated to be sustained by 2,092-6,056 individual engineered LtLP clones, as previously predicted by Scala et al. $(115,119)$.

\section{B Cells}

In contrast to the outstanding $\mathrm{T}$-cell recovery achieved across gene therapy clinical trials performed in SCID-X1 patients, B-cell reconstitution has been, in general, much more variable. Thus, in those SCID-X1 children treated with $\gamma \mathrm{RVs}\left(1^{\text {st }}\right.$ and $2^{\text {nd }}$ generation) in the absence of conditioning, only a partial and non-sustained recovery of B-cell function was achieved, which was in line with the absence or extremely reduced numbers of transgene marked B-cells $(58,59,63,73)$. Reduced levels of IgM and IgA were reported in $\approx 15 \%-70 \%$ and $\approx 30 \%-60 \%$ of patients, respectively, IgG evaluation being difficult to interpret because of IgRT, which is usually administrated to these patients. In addition, successful IgRT withdrawal is typically considered in itself as a marker of B-cell function correction, and 7/17 patients treated with $1^{\text {st }}$ generation $\gamma \mathrm{RVs}$ and all treated with $2^{\text {nd }}$ generation $\gamma \mathrm{RVs}$ remained on IgRT in the last reported follow-up $(63,73,74)$. It is noteworthy that the parameters used to inform discontinuation of IgRT were not always the same, and included the T-cell numbers (74), IgA and IgM levels $(59,73)$, or clinical parameters (74).

Despite the widely used and undeniable utility of serum antibodies to evaluate the B-cell response, these might not reflect accurately the ongoing B-cell response (120), as antibodies are principally produced by long-living plasma cells, which are located mainly in BM niches for years or even decades (121-123). In which case, the detection of serum Ig levels over time observed in some SCID-X1 infants after gene therapy may reflect an early but temporal recovery of B-cell function. This would be in line with the initial response to vaccination observed in some patients, but generally suboptimal and non-sustained over time, and most likely linked to the decrease in the percentage of transduced B-cells (from $1 \%$ during the first 2 years to $<0.1 \% 6-10$ years after therapy) (74). Accordingly, normal serum IgM levels is not a good predictor of Bcell response in SCID-X1/JAK3 SCID patients after HSCT, despite it being a widely parameter used to decide the withdraw of IgRT (37). Consequently, alternative parameters should be also considered to evaluate recovery of B-cell function. Vaccination response is a more reliable and predictive indicator, and has been extensively measured in SCID-X1 patients after treatment, using a wide number of polysaccharide and protein antigens $(37,73,74)$. However, despite its utility (124), this approach is impeded by the use of IgRT and cannot be performed in all patients. One possible solution might be the immunization with neoantigens, as the T-cell dependent $\Phi$ X174 bacteriophage, which has already been used in SCID-X1 treated with HSCT (45). On the other hand, other measures such as presence of class switched memory B-cells or in vitro stimulation with IL-21, have demonstrated to be very useful for the evaluation of B-cell function recovery, showing a good correlation with vaccination response (37). This might help to inform clinical decisions, such as the initiation of immunization as well as the withdrawal of $\operatorname{IgRT}(14,125)$. In line with the disappointing vaccination results obtained in SCID-X1 children treated with $1^{\text {st }}$ and $2^{\text {nd }}$ generation $\gamma \mathrm{RVs}$ without conditioning (63, $73,74)$, memory B-cells were reduced in the last follow-up in virtually all the patients. Accordingly, no response to IL-21 was observed, despite some proliferation was detected after stimulation with CD40L and IL-4 (74), probably through the activation of IL-13 receptor (without $\gamma c)(45,126)$.

In summary, gene therapy based on $\gamma \mathrm{RVs}$ in the absence of conditioning failed to deliver a sustained and optimal B-cell recovery, despite successful $\mathrm{T}$-cell reconstitution and therefore 
restoration of $\mathrm{T}$ cell help (Figures 4A, B). The reason for these results is most likely the absence (or extremely low) percentages of corrected B-cell years after the treatment, due to the reduced engraftment of corrected progenitors (Figure 4B), and hence a maintained defect in IL-21 signaling in B-cells $(14,74,125)$. This effect is also observed in those SCID-X1 patients with reduced Bcell chimerism after HSCT (37). Because of the problems linked to a defective B-cell recovery, such as higher risk of pulmonary infections and chronic lung disease, as well as the reduced quality of life associated with the dependence to $\operatorname{IgRT}(36)$, improvement in the $\mathrm{B}$-cell reconstitution is an important consideration in SCID-X1 treatments. Therefore, according to the good results obtained using reduced-intensity conditioning in gene therapy treatment for ADA-SCID patients $(81,113)$, as well as in pre-clinical models of SCID-X1 (112), low-dose conditioning regimens have now been applied to gene therapy clinical trials for SCID-X1 (Table 1) (Figure 4C).

Preliminary results of trials using LVs and conditioning in SCID-X1 patients show promising results regarding B-cell function recovery. In the first clinical trial performed in five patients between 7 and 22 years old in which previous HSCT failed, marked B-cells appeared early after the infusion of corrected cells, and B-cell recovery was demonstrated by the increase of IgM from 3 months after therapy (62). Moreover, in two patients followed-up for more time (24-36 months), reconstitution of $\mathrm{B}$-cell function was confirmed by the
A

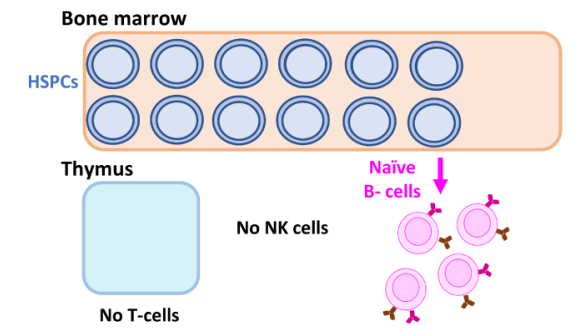

- No T-cell production

- No NK-cell production

- No humoral response
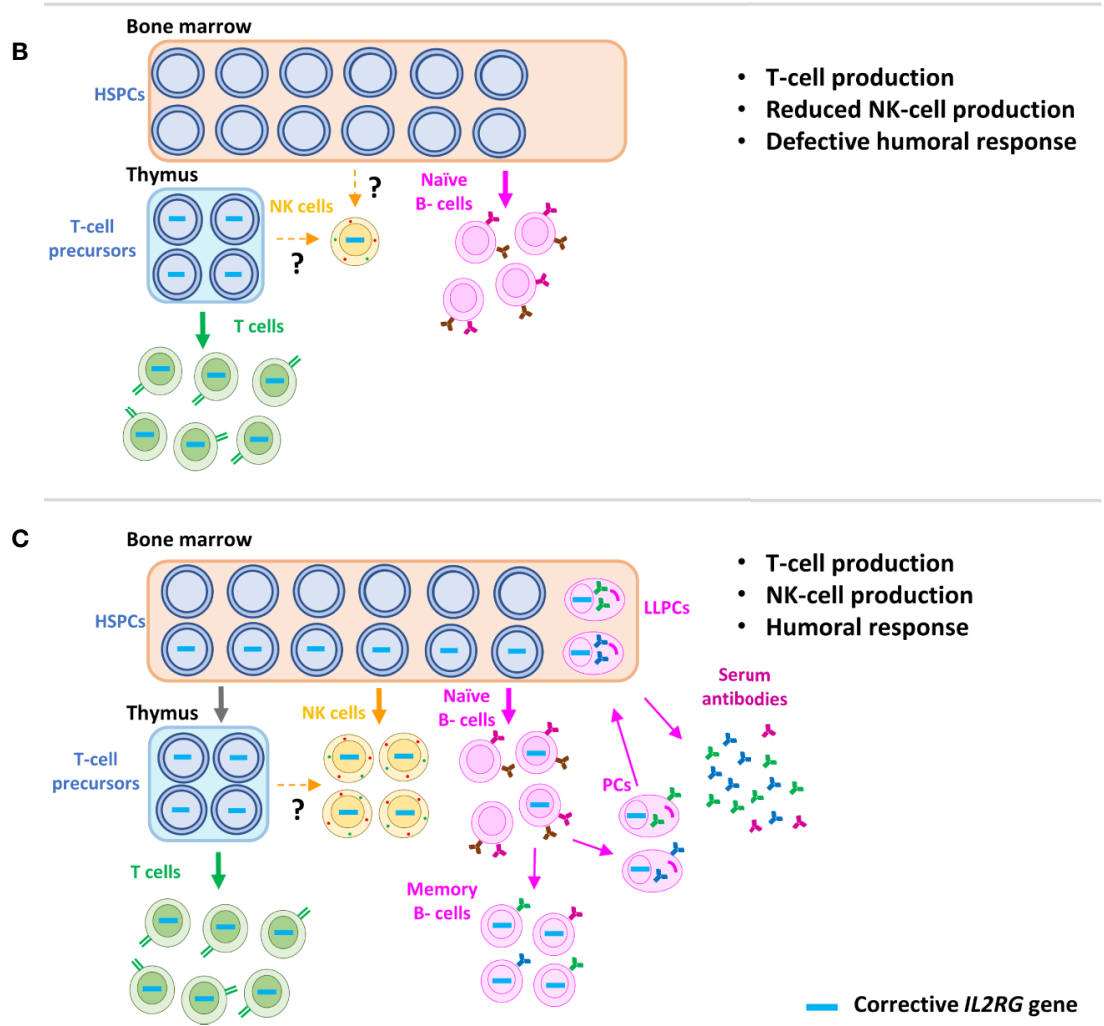

FIGURE 4 | Schematic representation of immune reconstitution in SCID-X1 patients after gene therapy. Characteristic phenotype of SCID-X1 patients, with absence of T and NK cells and only presence of naiive B-cells, but without differentiation capacity (T-B+NK- phenotype) (A). Immune reconstitution accomplished after the gene therapy using $\gamma R V$ s in the absence of conditioning treatment. Corrected progenitors seed the thymus and a sufficient reconstitution of T-cells is achieved. However, due to the loss of corrected hematopoietic stem cells in bone marrow, only a partial and non-sustained recovery of NK cells and B cells is observed. Interestingly, few marked NK cells are detected years after the therapy, most likely produced from a common long-term lymphoid progenitor, which might be in thymus or bone marrow (B). Immune recovery of SCID-X1 patients after gene therapy using LVs and conditioning treatment, which favor the engraftment of corrected hematopoietic stem cells (C). HSPCs, hematopoietic stem and progenitor cells; PCs, plasma cells; LLPCs, long-living plasma cells. 
vaccination response, in vitro stimulation by IL-21, normal IgG after IgRT withdrawal and the presence of $\operatorname{IgG}^{+}$memory B-cells. Interestingly, the humoral reconstitution corresponded with the eradication of chronic norovirus infection (62). Regarding the recovery of B-cell function in SCID-X1 infants treated with this approach, preliminary results reported by Mamcarz et al. show a normalization of IgM in $7 / 8$ patients 3-6 months after the gene therapy, protective vaccination response in most cases evaluated and independence of IgRT in 4/8 cases (60). Vector-marked Bcells were detected at 2-3 months and $\mathrm{VCN}$ in B-cells remained relatively high and stable (as well as in other lineages) throughout the follow-up time (up to 18 months) (60). Interestingly, as de Ravin et al. pointed out, LVs and their capacity to target HSPCs more efficiently also might have an important role to improve the engraftment in these patients (62). In conclusion, preliminary reports of the use of LVs and low-dose conditioning treatment show very promising results with regard to B-cell reconstitution, although longer follow-up will be necessary to confirm these findings.

\section{NK Cells}

Despite the early increase observed in NK cells 2-4 weeks after $\gamma \mathrm{RV}$-based gene therapy in absence of conditioning treatment $(58,59)$, this was not sustained. Thus, absolute numbers were below normal levels compared to age-matched healthy donors at last follow-up, and levels of marked NK cells also decreased over time $(63,73,74)$. There is scarce information available about the phenotype or functional capacities of these corrected NK cells. Although efficient capacity to kill target cells $(\mathrm{K} 562)(6,58)$, other studies have reported a defective expression of NK-cell receptors such as NKp46 and NKG2D (127). Strikingly, a transient increase was also observed in patients who developed T-ALL, most likely as a secondary response to the clonal proliferation (74). Recently, Izotova et al. demonstrated the presence of a reduced number of NK cells up to 19 years after the treatment, and 15 years after the loss of corrected HSPCs (115). These NK cells showed a normal expression of several markers (Granzyme $\mathrm{B}$, perforin, CD94), but a decreased percentage of CD56 ${ }^{\mathrm{dim}}$ $\mathrm{CD}^{+} 6^{+}$(which is the major subset in healthy donors), in line with previous results (127). Interestingly, due to the high levels of shared integration sites with naïve T-cells, an intriguing possibility is that these NK cells are most produced by a longlived common LtLP (Figure 4B) (115). However, $\gamma \mathrm{RV}$ gene therapy in the absence of conditioning did not favor the development and survival of NK cells as efficiently as T-cells (74).

As for B-cells, the introduction of pre-conditioning might improve NK cell reconstitution (73) due to the increase in numbers of engrafted HSPCs (Figure 4C). Accordingly, preliminary reports from trials using LVs and low-dose conditioning showed a relatively high and stable VCN in NK cells over time, showing age-matched comparable values in most cases $(60,62)$ and normal expression of natural cytotoxic receptors (62). Interestingly, in one patient with HPV related severe warts, a clear improvement was coincident with an increase in NK cells (62). Of note, the high prevalence of warts related to HPV infection observed in patients with SCID-X1 after HSCT and gene therapy (128) has been suggested to be associated with persistent NK defects (52). However, the clinical consequences of NK cell deficiency has been a matter of debate $(44,129-131)$, and alternative hypotheses to explain the prevalence of these infections in SCID-X1 patients have been put forward, including defective $\gamma c$ signaling in keratinocytes (128). In conclusion, promising results have been reported with the use of LVs and conditioning treatment regarding the NK-cell reconstitution, although long-term follow-up and results from other clinical trials, hopefully including more phenotypic and functional studies, are needed to confirm them.

\section{Immune Reconstitution Differences After Gene Therapy vs. HSCT in SCID-X1 Patients}

To date, only one published paper has directly compared immune recovery in SCID-X1 patients treated with gene therapy and HSCT (127), most likely due to the relatively low number of SCID-X1 patients treated with gene therapy so far. This was a retrospective study conducted in one center, which compared 13 patients treated with HLA-mismatched HSCT (receiving two doses of rabbit anti-thymoglobulin on days -2 and -1 ) and 14 patients treated with gene therapy (using $1^{\text {st }}$ generation $\gamma \mathrm{RVs}$ or $2^{\text {nd }}$ generation SIN- $\gamma \mathrm{RV}$ s in the absence of pre-conditioning, except one patient receiving fludarabine on days -3 and -2 to reduce the number of maternally engrafted Tcells). Overall, results showed faster T-cell reconstitution in patients treated with gene therapy vs. HSCT, with a high number of total T-cells, $\mathrm{T} \mathrm{CD} 4^{+}$and $\mathrm{T} \mathrm{CD}^{+}$, as well as RTE cells $\left(\mathrm{CD} 4^{+}, \mathrm{CD} 45 \mathrm{RA}^{+}, \mathrm{CD} 31^{+}\right)$at 6 and 12 months after treatment. However, the use of ATG prior to HSCT could also play a role in slower immune reconstitution in these patients. These differences continued being observed 5 years after the treatment for RTE cells, but disappeared for the other T-cell subsets (127). Rapid T-cell recovery during the first months after engraftment is essential to prevent accumulation of dangerous infections, which are one of the main causes of death in patients treated with HSCT (38).

On the other hand, no differences were observed in the distribution of B-cell subpopulations or IgA levels between both groups of patients, although IgM levels were higher 24 months after treatment in gene therapy group. Most likely due to the absence of conditioning, B-cell function remained defective in all patients, although in $4 / 12$ patients treated with gene therapy it was possible to stop IgRT (all of them treated with $1^{\text {st }}$ generation $\gamma \mathrm{RVs}$ ) vs. in none of those treated with HSCT (127). Similarly, NK-cell reconstitution was not achieved in any of the patients evaluated from both groups, despite a higher number of cells was observed in those patients treated with gene therapy. The subset of $\mathrm{CD} 56^{\mathrm{dim}} \mathrm{CD} 16^{+}$cells as well as the expression of NKp46 and NKG2D were reduced in both groups of patients. In contrast, CD56 expression was reduced in HSCT patients vs. healthy donors and patients treated with gene therapy (127).

In conclusion, this informative study demonstrated faster immune reconstitution in SCID-X1 patients treated with gene therapy vs. HSCT, especially of T-cells, leading to more rapid 
resolution of some infections and a shorter duration of infectionrelated hospitalization (127). One explanation for this superior immune reconstitution during the first month might be the absence of GvHD or the use of younger autologous stem cells (132). Nevertheless, larger multicenter studies including more patients, as well as different therapeutic approaches used in both HSCT and gene therapy should be carried out to confirm these results.

\section{CONCLUSIONS AND FUTURE PERSPECTIVES}

Gene therapy treatments for patients with SCID-X1 have improved considerably in the last 20 years. The promising results of the first clinical trials $(6,58,59)$ were overshadowed by the occurrence of T-ALL in several patients $(7,79)$. However, the development of new safer $\gamma \mathrm{RV}$ s and application in new clinical trials have showed encouraging results, with similar efficacy $v s$. previous trials and absence of leukemogenesis so far (63). Most recently, the use of LVs and the introduction of low-intensity conditioning have also improved the safety and immune reconstitution (60), even in older patients (62). The introduction of conditioning has played a particularly important role in improved multilineage immune recovery in SCID-X1 and other PIDs, regardless of the vector used $(60,62,103,109,113)$.

$\mathrm{CD}^{+}{ }^{+}$and naïve $\mathrm{CD} 4^{+}$T-cell counts at 6 and 12 months after HSCT have now been identified as predictive biomarkers for the long-term T-cell reconstitution and overall survival in SCID patients (34). The discovery of these kind of markers in SCID$\mathrm{X} 1$ patients after gene therapy might facilitate the identification of those cases in which the treatment is failing, and would allow rapid additional intervention through a new infusion of gene corrected cells or progression to conditioned allogeneic HSCT, preventing organ damage and other complications arising from insufficient immune reconstitution. On the other hand, T-cell reconstitution has been reported to be faster after gene therapy vs. HSCT in patients with SCID-X1 (127). If these results are confirmed with larger series, this might change the current place of gene therapy in treatment protocols for SCID-X1 (31). However, these studies are sometimes hampered by the lack of standardized guidelines for the evaluation of immune reconstitution. A possible solution could be the use of international recommendations, such as those recently published by the Pediatric Blood and Marrow Transplant Consortium for the screening and management of SCID patients after HSCT (124).

Huge efforts are being put into the development of superior viral vectors for clinical use. Thus, improvements in LV design and production, as well as the culture and transduction protocols have been developed (111,133-135), which might help to achieve a more efficient and cheaper manufacturing $(133,134)$, as well as better immune reconstitution (135). Furthermore, the application of conditioning treatment based on biologic agents for stem cell depletion (e.g. monoclonal antibodies), with the objective to avoid the toxic effects of classical treatments, is very promising (55-57).
Finally, despite the encouraging results using vector-based gene therapy in SCID-X1 patients and the absence of leukemogenesis with the SIN- $\gamma$ RVs and SIN-LVs so far, concerns surrounding insertional mutagenesis as well as the goal to obtain physiological expression patterns, have driven the search of new alternatives. Accordingly, gene editing tools are being explored for the treatment of several monogenic diseases, including PIDs. Despite the absence of clinical trials using these approaches for SCID-X1 treatment so far, recent in vitro and in vivo pre-clinical studies using zinc-finger nucleases (ZFNs) (136, 137), transcription activator-like effector nucleases (TALENs) (138), RNA-guided nucleases (CRISPR/Cas) (139) and adenoassociated viruses (140) have shown very promising results. [Booth et al. (141), Zhang et al. (142), and Rai et al. (143) recently reviewed the state-of-the-art of gene editing tools in primary immunodeficiencies]. However, the reduced efficiency of homologous recombination in HSPCs is a potential hurdle to be overcome before successful clinical application can be contemplated, even where a powerful selective growth advantage exists for corrected lineages (136, 137, 142). Widespread application of ex vivo gene therapy treatments remains complex because of the need for HSPC manipulation using elaborate protocols and sophisticated facilities $(144,145)$. The use of in vivo gene therapy through the direct delivery of the viral vector has also been proposed as a possible alternative, with encouraging results obtained in SCID-X1 canine models (144-146).

In conclusion, gene therapy approaches for the treatment of SCID-X1 have advanced considerably since the first clinical trials were performed. Safer vectors have been developed and the introduction of conditioning treatments have produced very promising clinical outcomes with limited toxicities. Longer follow-up and study of a larger numbers of patients is necessary to fully evaluate the place of gene therapy alongside conventional HSCT. Furthermore, the reduction of costs and the worldwide accessibility are important practicalities to consider. Finally, the application of new tools such as gene editing have the potential to revolutionize the gene therapy field for the treatment of SCID-X1 and other devastating monogenic diseases.

\section{AUTHOR CONTRIBUTIONS}

EB and AT conceived the manuscript. All authors contributed to the article and approved the submitted version.

\section{FUNDING}

EB is supported by a postdoctoral grant from Fundación Alfonso Martín Escudero (Spain). AT is supported by The Wellcome Trust (217112/Z/19/Z), and all authors are supported by National Institute for Health Research Biomedical Research Centre at Great Ormond Street Hospital for Children NHS Foundation Trust. Funds were received from University College London (UCL) for open access publication fees. 


\section{REFERENCES}

1. Tangye SG, Al-Herz W, Bousfiha A, Chatila T, Cunningham-Rundles C, Etzioni A, et al. Human Inborn Errors of Immunity: 2019 Update on the Classification from the International Union of Immunological Societies Expert Committee. J Clin Immunol (2020) 40:24-64. doi: 10.1007/s10875019-00737-x

2. Puck JM. Newborn screening for severe combined immunodeficiency and T-cell lymphopenia. Immunol Rev (2019) 287:241-52. doi: 10.1111/ imr.12729

3. Dvorak CC, Haddad E, Buckley RH, Cowan MJ, Logan B, Griffith LM, et al. The genetic landscape of severe combined immunodeficiency in the United States and Canada in the current era (2010-2018). J Allergy Clin Immunol (2019) 143:405-7. doi: 10.1016/j.jaci.2018.08.027

4. Buckley RH. Advances in the understanding and treatment of human severe combined immunodeficiency. Immunol Res (2000) 22:237-51. doi: 10.1385/ IR:22:2-3:237

5. Staal FJT, Aiuti A, Cavazzana M. Autologous Stem-Cell-Based Gene Therapy for Inherited Disorders: State of the Art and Perspectives. Front Pediatr (2019) 7:443:443. doi: 10.3389/fped.2019.00443

6. Cavazzana-Calvo M, Hacein-Bey S, de Saint Basile G, Gross F, Yvon E, Nusbaum P, et al. Gene therapy of human severe combined immunodeficiency (SCID)-X1 disease. Science (2000) 288:669-72. doi: $10.1126 /$ science.288.5466.669

7. Hacein-Bey-Abina S, von Kalle C, Schmidt M, Le Deist F, Wulffraat N, McIntyre E, et al. A serious adverse event after successful gene therapy for Xlinked severe combined immunodeficiency. N Engl J Med (2003) 348:255-6. doi: 10.1056/NEJM200301163480314

8. Noguchi M, Yi H, Rosenblatt HM, Filipovich AH, Adelstein S, Modi WS, et al. Interleukin-2 receptor gamma chain mutation results in X-linked severe combined immunodeficiency in humans. Cell (1993) 73:147-57. doi: 10.1016/0092-8674(93)90167-O

9. Puck JM, Deschenes SM, Porter JC, Dutra AS, Brown CJ, Willard HF, et al. The interleukin-2 receptor gamma chain maps to Xq13.1 and is mutated in X-linked severe combined immunodeficiency, SCIDX1. Hum Mol Genet (1993) 2:1099-104. doi: 10.1093/hmg/2.8.1099

10. Kumrah R, Vignesh P, Patra P, Singh A, Anjani G, Saini P, et al. Genetics of severe combined immunodeficiency. Genes Dis (2020) 7:52-61. doi: 10.1016/ j.gendis.2019.07.004

11. Lim CK, Abolhassani H, Appelberg SK, Sundin M, Hammarström L. IL2RG hypomorphic mutation: identification of a novel pathogenic mutation in exon 8 and a review of the literature. Allergy Asthma Clin Immunol Off J Can Soc Allergy Clin Immunol (2019) 15:2. doi: 10.1186/s13223-018-0317-y

12. Leonard WJ, Lin J-X, O'Shea JJ. The $\gamma(\mathrm{c})$ Family of Cytokines: Basic Biology to Therapeutic Ramifications. Immunity (2019) 50:832-50. doi: 10.1016/ j.immuni.2019.03.028

13. Alpdogan O, van den Brink MRM. IL-7 and IL-15: therapeutic cytokines for immunodeficiency. Trends Immunol (2005) 26:56-64. doi: 10.1016/ j.it.2004.11.002

14. Recher M, Berglund LJ, Avery DT, Cowan MJ, Gennery AR, Smart J, et al. IL-21 is the primary common gamma chain-binding cytokine required for human B-cell differentiation in vivo. Blood (2011) 118:6824-35. doi: 10.1182/blood-2011-06-362533

15. Gaspar HB, Qasim W, Davies EG, Rao K, Amrolia PJ, Veys P. How I treat severe combined immunodeficiency. Blood (2013) 122:3749-58. doi: 10.1182/blood-2013-02-380105

16. Tuovinen EA, Grönholm J, Öhman T, Pöysti S, Toivonen R, Kreutzman A, et al. Novel Hemizygous IL2RG p.(Pro58Ser) Mutation Impairs IL-2 Receptor Complex Expression on Lymphocytes Causing X-Linked Combined Immunodeficiency. J Clin Immunol (2020) 40:503-14. doi: 10.1007/s10875-020-00745-2

17. Kawai T, Saito M, Nishikomori R, Yasumi T, Izawa K, Murakami T, et al. Multiple reversions of an IL2RG mutation restore T cell function in an Xlinked severe combined immunodeficiency patient. J Clin Immunol (2012) 32:690-7. doi: 10.1007/s10875-012-9684-1

18. Stephan V, Wahn V, Le Deist F, Dirksen U, Broker B, Muller-Fleckenstein I, et al. Atypical X-linked severe combined immunodeficiency due to possible spontaneous reversion of the genetic defect in T cells. N Engl J Med (1996) 335:1563-7. doi: 10.1056/NEJM199611213352104

19. Speckmann C, Pannicke U, Wiech E, Schwarz K, Fisch P, Friedrich W, et al. Clinical and immunologic consequences of a somatic reversion in a patient with X-linked severe combined immunodeficiency. Blood (2008) 112:40907. doi: 10.1182/blood-2008-04-153361

20. Hsu AP, Pittaluga S, Martinez B, Rump AP, Raffeld M, Uzel G, et al. IL2RG reversion event in a common lymphoid progenitor leads to delayed diagnosis and milder phenotype. J Clin Immunol (2015) 35:449-53. doi: 10.1007/s10875-015-0174-0

21. Kuijpers TW, van Leeuwen EMM, Barendregt BH, Klarenbeek P, aan de Kerk DJ, Baars PA, et al. A reversion of an IL2RG mutation in combined immunodeficiency providing competitive advantage to the majority of CD8 + T cells. Haematologica (2013) 98:1030-8. doi: 10.3324/haematol. 2012.077511

22. Quinn J, Orange JS, Modell V, Modell F. The case for severe combined immunodeficiency (SCID) and $\mathrm{T}$ cell lymphopenia newborn screening: saving lives...one at a time. Immunol Res (2020) 68:48-53. doi: 10.1007/ s12026-020-09117-9

23. Kalina T, Bakardjieva M, Blom M, Perez-Andres M, Barendregt B, Kanderová V, et al. EuroFlow Standardized Approach to Diagnostic Immunopheneotyping of Severe PID in Newborns and Young Children. Front Immunol (2020) 11:371. doi: 10.3389/fimmu.2020.00371

24. van Der Burg M, Kalina T, Perez-Andres M, Vlkova M, Lopez-Granados E, Blanco E, et al. The EuroFlow PID orientation tube for flow cytometric diagnostic screening of primary immunodeficiencies of the lymphoid system. Front Immunol (2019) 10:246. doi: 10.3389/fimmu.2019.00246

25. Shearer WT, Dunn E, Notarangelo LD, Dvorak CC, Puck JM, Logan BR, et al. Establishing diagnostic criteria for severe combined immunodeficiency disease (SCID), leaky SCID, and Omenn syndrome: the Primary Immune Deficiency Treatment Consortium experience. J Allergy Clin Immunol (2014) 133:1092-8. doi: 10.1016/j.jaci.2013.09.044

26. Purswani P, Meehan CA, Kuehn HS, Chang Y, Dasso JF, Meyer AK, et al. Two Unique Cases of X-linked SCID: A Diagnostic Challenge in the Era of Newborn Screening. Front Pediatr (2019) 7:55. doi: 10.3389/fped.2019. 00055

27. Bustamante Ogando JC, Partida Gaytán A, Aldave Becerra JC, Álvarez Cardona A, Bezrodnik L, Borzutzky A, et al. Latin American consensus on the supportive management of patients with severe combined immunodeficiency. J Allergy Clin Immunol (2019) 144:897-905. doi: 10.1016/j.jaci.2019.08.002

28. Haddad E, Hoenig M. Hematopoietic Stem Cell Transplantation for Severe Combined Immunodeficiency (SCID). Front Pediatr (2019) 7:481. doi: 10.3389/fped.2019.00481

29. Walter JE, Heimall J. CMV-Seropositive Mothers of SCID: To Breastfeed or Not? J Allergy Clin Immunol Pract (2019) 7:2866-7. doi: 10.1016/ j.jaip.2019.08.028

30. Dorsey MJ, Dvorak CC, Cowan MJ, Puck JM. Treatment of infants identified as having severe combined immunodeficiency by means of newborn screening. J Allergy Clin Immunol (2017) 139:733-42. doi: 10.1016/ j.jaci.2017.01.005

31. European Society for Immunodeficiencies. Bone Marrow Transplantation \& Gene Therapy. EBMT/ ESID guidelines for haematopoietic stem cell transplantation for primary immunodeficiencies. Available at: https://esid. org/layout/set/print/Working-Parties/Inborn-Errors-Working-PartyIEWP/Resources/UPDATED!-EBMT-ESID-GUIDELINES-FORHAEMATOPOIETIC-STEM-CELL-TRANSPLANTATION-FOR-PI (Accessed September 15, 2020).

32. Gatti RA, Meuwissen HJ, Allen HD, Hong R, Good RA. Immunological reconstitution of sex-linked lymphopenic immunological deficiency. Lancet (London England) (1968) 2:1366-9. doi: 10.1016/s0140-6736(68)92673-1

33. Gennery AR, Lankester A. Inborn Errors Working Party (IEWP) of the European Society for Blood and Marrow Transplantation (EBMT). Long Term Outcome and Immune Function After Hematopoietic Stem Cell Transplantation for Primary Immunodeficiency. Front Pediatr (2019) 7:381. doi: 10.3389/fped.2019.00381

34. Haddad E, Logan BR, Griffith LM, Buckley RH, Parrott RE, Prockop SE, et al. SCID genotype and 6-month posttransplant CD4 count predict survival and 
immune recovery. Blood (2018) 132:1737-49. doi: 10.1182/blood-2018-03840702

35. Gennery AR, Slatter MA, Grandin L, Taupin P, Cant AJ, Veys P, et al. Transplantation of hematopoietic stem cells and long-term survival for primary immunodeficiencies in Europe: entering a new century, do we do better? J Allergy Clin Immunol (2010) 126:602-11. doi: 10.1016/j.jaci.2010.06.015

36. Abd Hamid IJ, Slatter MA, McKendrick F, Pearce MS, Gennery AR. Longterm outcome of hematopoietic stem cell transplantation for IL2RG/JAK3 SCID: a cohort report. Blood (2017) 129:2198-201. doi: 10.1182/blood-201611-748616

37. Miggelbrink AM, Logan BR, Buckley RH, Parrott RE, Dvorak CC, Kapoor N, et al. B-cell differentiation and IL-21 response in IL2RG/JAK3 SCID patients after hematopoietic stem cell transplantation. Blood (2018) 131:2967-77. doi: 10.1182/blood-2017-10-809822

38. Pai S-Y, Logan BR, Griffith LM, Buckley RH, Parrott RE, Dvorak CC, et al. Transplantation outcomes for severe combined immunodeficiency, 20002009. N Engl J Med (2014) 371:434-46. doi: 10.1056/NEJMoa1401177

39. Railey MD, Lokhnygina Y, Buckley RH. Long-term clinical outcome of patients with severe combined immunodeficiency who received related donor bone marrow transplants without pretransplant chemotherapy or post-transplant GVHD prophylaxis. J Pediatr (2009) 155:834-40.e1. doi: 10.1016/j.jpeds.2009.07.049

40. Buckley RH. Transplantation of hematopoietic stem cells in human severe combined immunodeficiency: longterm outcomes. Immunol Res (2011) 49:25-43. doi: 10.1007/s12026-010-8191-9

41. Dvorak CC, Hassan A, Slatter MA, Honig M, Lankester AC, Buckley RH, et al. Comparison of outcomes of hematopoietic stem cell transplantation without chemotherapy conditioning by using matched sibling and unrelated donors for treatment of severe combined immunodeficiency. J Allergy Clin Immunol (2014) 134:935-43.e15. doi: 10.1016/j.jaci.2014.06.021

42. Heimall J, Cowan MJ. Long term outcomes of severe combined immunodeficiency: therapy implications. Expert Rev Clin Immunol (2017) 13:1029-40. doi: 10.1080/1744666X.2017.1381558

43. Heimall J, Puck J, Buckley R, Fleisher TA, Gennery AR, Neven B, et al. Current Knowledge and Priorities for Future Research in Late Effects after Hematopoietic Stem Cell Transplantation (HCT) for Severe Combined Immunodeficiency Patients: A Consensus Statement from the Second Pediatric Blood and Marrow Transplant Consortium. Biol Blood Marrow Transplant (2017) 23:379-87. doi: 10.1016/j.bbmt.2016.12.619

44. Neven B, Leroy S, Decaluwe H, Le Deist F, Picard C, Moshous D, et al. Longterm outcome after hematopoietic stem cell transplantation of a singlecenter cohort of 90 patients with severe combined immunodeficiency. Blood (2009) 113:4114-24. doi: 10.1182/blood-2008-09-177923

45. Buckley RH, Win CM, Moser BK, Parrott RE, Sajaroff E, Sarzotti-Kelsoe M. Post-transplantation B cell function in different molecular types of SCID. J Clin Immunol (2013) 33:96-110. doi: 10.1007/s10875-012-9797-6

46. Haddad E, Leroy S, Buckley RH. B-cell reconstitution for SCID: should a conditioning regimen be used in SCID treatment? J Allergy Clin Immunol (2013) 131:994-1000. doi: 10.1016/j.jaci.2013.01.047

47. Lee AY, Frith K, Schneider L, Ziegler JB. Haematopoietic stem cell transplantation for severe combined immunodeficiency: Long-term health outcomes and patient perspectives. J Paediatr Child Health (2017) 53:76670. doi: $10.1111 /$ jpc. 13560

48. White H, Thrasher A, Veys P, Kinnon C, Gaspar HB. Intrinsic defects of B cell function in X-linked severe combined immunodeficiency. Eur J Immunol (2000) 30:732-7. doi: 10.1002/1521-4141(200003)30:3<732::AID-IMMU7 $32>3.0 . \mathrm{CO} ; 2-\mathrm{L}$

49. Deal C, Thauland TJ, Stiehm ER, Garcia-Lloret MI, Butte MJ. Intact B-Cell Signaling and Function With Host B-Cells 47 Years After Transplantation for XSCID. Front Immunol (2020) 11:415. doi: 10.3389/fimmu.2020.00415

50. Liu A, Vosshenrich CAJ, Lagresle-Peyrou C, Malassis-Seris M, Hue C, Fischer A, et al. Competition within the early B-cell compartment conditions B-cell reconstitution after hematopoietic stem cell transplantation in nonirradiated recipients. Blood (2006) 108:1123-8. doi: 10.1182/blood-2006-01-0061

51. Buckley RH. B-cell function in severe combined immunodeficiency after stem cell or gene therapy: a review. J Allergy Clin Immunol (2010) 125:790-7. doi: 10.1016/j.jaci.2010.02.012
52. Kamili QUA, Seeborg FO, Saxena K, Nicholas SK, Banerjee PP, Angelo LS, et al. Severe cutaneous human papillomavirus infection associated with natural killer cell deficiency following stem cell transplantation for severe combined immunodeficiency. J Allergy Clin Immunol (2014) 134:1451-3.e1. doi: 10.1016/j.jaci.2014.07.009

53. Keller MD. Improving transplantation for IL2RG/JAK3 SCID. Blood (2017) 129:2049-50. doi: 10.1182/blood-2017-03-770974

54. Savic RM, Cowan MJ, Dvorak CC, Pai S-Y, Pereira L, Bartelink IH, et al. Effect of weight and maturation on busulfan clearance in infants and small children undergoing hematopoietic cell transplantation. Biol Blood Marrow Transplant (2013) 19:1608-14. doi: 10.1016/j.bbmt.2013.08.014

55. Chhabra A, Ring AM, Weiskopf K, Schnorr PJ, Gordon S, Le AC, et al. Hematopoietic stem cell transplantation in immunocompetent hosts without radiation or chemotherapy. Sci Transl Med (2016) 8:351ra105. doi: 10.1126/scitranslmed.aae0501

56. Castiello MC, Bosticardo M, Sacchetti N, Calzoni E, Fontana E, Yamazaki Y, et al. Efficacy and safety of anti-CD45-Saporin as conditioning agent for RAG deficiency. J Allergy Clin Immunol (2020) (in press). doi: 10.1016/j.jaci.2020.04.033

57. Kwon H-S, Logan AC, Chhabra A, Pang WW, Czechowicz A, Tate K, et al. Anti-human CD117 antibody-mediated bone marrow niche clearance in nonhuman primates and humanized NSG mice. Blood (2019) 133:2104-8. doi: 10.1182/blood-2018-06-853879

58. Hacein-Bey-Abina S, Le Deist F, Carlier F, Bouneaud C, Hue C, De Villartay $\mathrm{J}-\mathrm{P}$, et al. Sustained correction of X-linked severe combined immunodeficiency by ex vivo gene therapy. N Engl J Med (2002) 346:1185-93. doi: 10.1056/NEJMoa012616

59. Gaspar HB, Parsley KL, Howe S, King D, Gilmour KC, Sinclair J, et al. Gene therapy of X-linked severe combined immunodeficiency by use of a pseudotyped gammaretroviral vector. Lancet (London England) (2004) 364:2181-7. doi: 10.1016/S0140-6736(04)17590-9

60. Mamcarz E, Zhou S, Lockey T, Abdelsamed H, Cross SJ, Kang G, et al. Lentiviral Gene Therapy Combined with Low-Dose Busulfan in Infants with SCID-X1. N Engl J Med (2019) 380:1525-34. doi: 10.1056/NEJMoa1815408

61. Chinen J, Davis J, De Ravin SS, Hay BN, Hsu AP, Linton GF, et al. Gene therapy improves immune function in preadolescents with $\mathrm{X}$-linked severe combined immunodeficiency. Blood (2007) 110:67-73. doi: 10.1182/blood2006-11-058933

62. De Ravin SS, Wu X, Moir S, Anaya-O’Brien S, Kwatemaa N, Littel P, et al. Lentiviral hematopoietic stem cell gene therapy for X-linked severe combined immunodeficiency. Sci Transl Med (2016) 8:335ra57. doi: 10.1126/scitranslmed.aad8856

63. Hacein-Bey-Abina S, Pai S-Y, Gaspar HB, Armant M, Berry CC, Blanche S, et al. A modified gamma-retrovirus vector for X-linked severe combined immunodeficiency. N Engl J Med (2014) 371:1407-17. doi: 10.1056/ NEJMoa1404588

64. Thrasher AJ, Hacein-Bey-Abina S, Gaspar HB, Blanche S, Davies EG, Parsley K, et al. Failure of SCID-X1 gene therapy in older patients. Blood (2005) 105:4255-7. doi: 10.1182/blood-2004-12-4837

65. Pike-Overzet K, van der Burg M, Wagemaker G, van Dongen JJM, Staal FJT. New insights and unresolved issues regarding insertional mutagenesis in Xlinked SCID gene therapy. Mol Ther (2007) 15:1910-6. doi: 10.1038/ sj.mt.6300297

66. Okuno Y, Hoshino A, Muramatsu H, Kawashima N, Wang X, Yoshida K, et al. Late-Onset Combined Immunodeficiency with a Novel IL2RG Mutation and Probable Revertant Somatic Mosaicism. J Clin Immunol (2015) 35:610-4. doi: 10.1007/s10875-015-0202-0

67. Lin CH, Kuehn HS, Thauland TJ, Lee CM, De Ravin SS, Malech HL, et al. Progressive B Cell Loss in Revertant X-SCID. J Clin Immunol (2020) 40:1001-9. doi: 10.1007/s10875-020-00825-3

68. Buckley RH. Molecular defects in human severe combined immunodeficiency and approaches to immune reconstitution. Annu Rev Immunol (2004) 22:62555. doi: 10.1146/annurev.immunol.22.012703.104614

69. Hacein-Bey H, Cavazzana-Calvo M, Le Deist F, Dautry-Varsat A, Hivroz C, Riviere I, et al. gamma-c gene transfer into SCID X1 patients' B-cell lines restores normal high-affinity interleukin-2 receptor expression and function. Blood (1996) 87:3108-16. doi: 10.1182/blood.V87.8.3108.bloodjournal8783108

70. Cavazzana-Calvo M, Hacein-Bey S, de Saint Basile G, De Coene C, Selz F, Le Deist F, et al. Role of interleukin-2 (IL-2), IL-7, and IL-15 in natural killer cell 
differentiation from cord blood hematopoietic progenitor cells and from gamma c transduced severe combined immunodeficiency X1 bone marrow cells. Blood (1996) 88:3901-9. doi: 10.1182/blood.V88.10.3901.bloodjournal88103901

71. Hacein-Bey S, Basile GD, Lemerle J, Fischer A, Cavazzana-Calvo M. gammac gene transfer in the presence of stem cell factor, FLT-3L, interleukin-7 (IL7), IL-1, and IL-15 cytokines restores T-cell differentiation from gammac(-) $\mathrm{X}$-linked severe combined immunodeficiency hematopoietic progenitor cells in murine fetal thymi. Blood (1998) 92:4090-7. doi: 10.1182/ blood.V92.11.4090

72. Whitwam T, Haskins ME, Henthorn PS, Kraszewski JN, Kleiman SE, Seidel NE, et al. Retroviral marking of canine bone marrow: long-term, high-level expression of human interleukin-2 receptor common gamma chain in canine lymphocytes. Blood (1998) 92:1565-75. doi: 10.1182/ blood.V92.5.1565

73. Gaspar HB, Cooray S, Gilmour KC, Parsley KL, Adams S, Howe SJ, et al. Long-term persistence of a polyclonal $\mathrm{T}$ cell repertoire after gene therapy for X-linked severe combined immunodeficiency. Sci Transl Med (2011) 3:97ra79. doi: 10.1126/scitranslmed.3002715

74. Hacein-Bey-Abina S, Hauer J, Lim A, Picard C, Wang GP, Berry CC, et al. Efficacy of gene therapy for X-linked severe combined immunodeficiency. $N$ Engl J Med (2010) 363:355-64. doi: 10.1056/NEJMoa1000164

75. Cavazzana M, Six E, Lagresle-Peyrou C, Andre-Schmutz I, Hacein-BeyAbina S. Gene Therapy for X-Linked Severe Combined Immunodeficiency: Where Do We Stand? Hum Gene Ther (2016) 27:108-16. doi: 10.1089/ hum.2015.137

76. Howe SJ, Mansour MR, Schwarzwaelder K, Bartholomae C, Hubank M, Kempski $\mathrm{H}$, et al. Insertional mutagenesis combined with acquired somatic mutations causes leukemogenesis following gene therapy of SCID-X1 patients. J Clin Invest (2008) 118:3143-50. doi: 10.1172/JCI35798

77. Hacein-Bey-Abina S, Garrigue A, Wang GP, Soulier J, Lim A, Morillon E, et al. Insertional oncogenesis in 4 patients after retrovirus-mediated gene therapy of SCID-X1. J Clin Invest (2008) 118:3132-42. doi: 10.1172/ JCI35700

78. Fischer A, Hacein-Bey-Abina S. Gene therapy for severe combined immunodeficiencies and beyond. J Exp Med (2020) 217:e20190607. doi: $10.1084 /$ jem. 20190607

79. Hacein-Bey-Abina S, Von Kalle C, Schmidt M, McCormack MP, Wulffraat $\mathrm{N}$, Leboulch $\mathrm{P}$, et al. LMO2-associated clonal T cell proliferation in two patients after gene therapy for SCID-X1. Science (2003) 302:415-9. doi: $10.1126 /$ science. 1088547

80. Aiuti A, Cattaneo F, Galimberti S, Benninghoff U, Cassani B, Callegaro L, et al. Gene therapy for immunodeficiency due to adenosine deaminase deficiency. N Engl J Med (2009) 360:447-58. doi: 10.1056/NEJMoa 0805817

81. Gaspar HB, Cooray S, Gilmour KC, Parsley KL, Zhang F, Adams S, et al. Hematopoietic stem cell gene therapy for adenosine deaminase-deficient severe combined immunodeficiency leads to long-term immunological recovery and metabolic correction. Sci Transl Med (2011) 3:97ra80. doi: 10.1126/scitranslmed.3002716

82. Cicalese MP, Ferrua F, Castagnaro L, Pajno R, Barzaghi F, Giannelli S, et al. Update on the safety and efficacy of retroviral gene therapy for immunodeficiency due to adenosine deaminase deficiency. Blood (2016) 128:45-54. doi: 10.1182/blood-2016-01-688226

83. Dave UP, Jenkins NA, Copeland NG. Gene therapy insertional mutagenesis insights. Science (2004) 303:333. doi: 10.1126/science.1091667

84. Woods N-B, Bottero V, Schmidt M, von Kalle C, Verma IM. Gene therapy: therapeutic gene causing lymphoma. Nature (2006) 440:1123. doi: 10.1038/ 4401123a

85. Pike-Overzet K, de Ridder D, Weerkamp F, Baert MRM, Verstegen MM, Brugman $\mathrm{MH}$, et al. Gene therapy: is IL2RG oncogenic in T-cell development? Nature (2006) 443:E5; discussion E6-7. doi: 10.1038/nature05218

86. Thrasher AJ, Gaspar HB, Baum C, Modlich U, Schambach A, Candotti F, et al. Gene therapy: X-SCID transgene leukaemogenicity. Nature (2006) 443: E5-6; discussion E6-7. doi: 10.1038/nature05219

87. Pike-Overzet K, de Ridder D, Weerkamp F, Baert MRM, Verstegen MMA, Brugman $\mathrm{MH}$, et al. Ectopic retroviral expression of LMO2, but not IL2Rgamma, blocks human T-cell development from CD34+ cells: implications for leukemogenesis in gene therapy. Leukemia (2007) 21:75463. doi: $10.1038 /$ sj.leu. 2404563

88. Ruggero $\mathrm{K}, \mathrm{Al}$-Assar O, Chambers JS, Codrington R, Brend T, Rabbitts TH. LMO2 and IL2RG synergize in thymocytes to mimic the evolution of SCIDX1 gene therapy-associated T-cell leukaemia. Leukemia (2016) 30:1959-62. doi: 10.1038/leu.2016.116

89. Martins VC, Busch K, Juraeva D, Blum C, Ludwig C, Rasche V, et al. Cell competition is a tumour suppressor mechanism in the thymus. Nature (2014) 509:465-70. doi: 10.1038/nature13317

90. Ginn SL, Hallwirth CV, Liao SHY, Teber ET, Arthur JW, Wu J, et al. Limiting Thymic Precursor Supply Increases the Risk of Lymphoid Malignancy in Murine X-Linked Severe Combined Immunodeficiency. Mol Ther Nucleic Acids (2017) 6:1-14. doi: 10.1016/j.omtn.2016.11.011

91. Qasim W, Gaspar HB, Thrasher AJ. "Darwinian” tumor-suppression model unsupported in clinical experience. Mol Ther (2014) 22:1562-3. doi: $10.1038 / \mathrm{mt} .2014 .147$

92. Wu X, Li Y, Crise B, Burgess SM. Transcription start regions in the human genome are favored targets for MLV integration. Science (2003) 300:174951. doi: $10.1126 /$ science. 1083413

93. Sharma A, Larue RC, Plumb MR, Malani N, Male F, Slaughter A, et al. BET proteins promote efficient murine leukemia virus integration at transcription start sites. Proc Natl Acad Sci U.S.A. (2013) 110:12036-41. doi: 10.1073/ pnas. 1307157110

94. De Rijck J, de Kogel C, Demeulemeester J, Vets S, El Ashkar S, Malani N, et al. The BET family of proteins targets moloney murine leukemia virus integration near transcription start sites. Cell Rep (2013) 5:886-94. doi: 10.1016/j.celrep.2013.09.040

95. Gupta SS, Maetzig T, Maertens GN, Sharif A, Rothe M, Weidner-Glunde M, et al. Bromo- and extraterminal domain chromatin regulators serve as cofactors for murine leukemia virus integration. J Virol (2013) 87:1272136. doi: 10.1128/JVI.01942-13

96. Braun CJ, Boztug K, Paruzynski A, Witzel M, Schwarzer A, Rothe M, et al. Gene therapy for Wiskott-Aldrich syndrome-long-term efficacy and genotoxicity. Sci Transl Med (2014) 6:227ra33. doi: 10.1126/ scitranslmed. 3007280

97. Stein S, Ott MG, Schultze-Strasser S, Jauch A, Burwinkel B, Kinner A, et al. Genomic instability and myelodysplasia with monosomy 7 consequent to EVI1 activation after gene therapy for chronic granulomatous disease. Nat Med (2010) 16:198-204. doi: 10.1038/nm.2088

98. Cooper AR, Lill GR, Shaw K, Carbonaro-Sarracino DA, Davila A, Sokolic R, et al. Cytoreductive conditioning intensity predicts clonal diversity in ADASCID retroviral gene therapy patients. Blood (2017) 129:2624-35. doi: 10.1182/blood-2016-12-756734

99. Aiuti A, Slavin S, Aker M, Ficara F, Deola S, Mortellaro A, et al. Correction of ADA-SCID by stem cell gene therapy combined with nonmyeloablative conditioning. Science (2002) 296:2410-3. doi: 10.1126/science.1070104

100. Shaw KL, Garabedian E, Mishra S, Barman P, Davila A, Carbonaro D, et al. Clinical efficacy of gene-modified stem cells in adenosine deaminasedeficient immunodeficiency. J Clin Invest (2017) 127:1689-99. doi: 10.1172/JCI90367

101. Thornhill SI, Schambach A, Howe SJ, Ulaganathan M, Grassman E, Williams $\mathrm{D}$, et al. Self-inactivating gammaretroviral vectors for gene therapy of $\mathrm{X}$ linked severe combined immunodeficiency. Mol Ther (2008) 16:590-8. doi: 10.1038/sj.mt.6300393

102. Zychlinski D, Schambach A, Modlich U, Maetzig T, Meyer J, Grassman E, et al. Physiological promoters reduce the genotoxic risk of integrating gene vectors. Mol Ther (2008) 16:718-25. doi: 10.1038/mt.2008.5

103. Pai S-Y, Thrasher AJ. Gene therapy for X-linked severe combined immunodeficiency: Historical outcomes and current status. J Allergy Clin Immunol (2020) 146:258-61. doi: 10.1016/j.jaci.2020.05.055

104. Moiani A, Miccio A, Rizzi E, Severgnini M, Pellin D, Suerth JD, et al. Deletion of the LTR enhancer/promoter has no impact on the integration profile of MLV vectors in human hematopoietic progenitors. PloS One (2013) 8:e55721. doi: 10.1371/journal.pone.0055721

105. Greene MR, Lockey T, Mehta PK, Kim Y-S, Eldridge PW, Gray JT, et al. Transduction of human CD34+ repopulating cells with a self-inactivating 
lentiviral vector for SCID-X1 produced at clinical scale by a stable cell line. Hum Gene Ther Methods (2012) 23:297-308. doi: 10.1089/hgtb.2012.150

106. Zhou S, Mody D, DeRavin SS, Hauer J, Lu T, Ma Z, et al. A self-inactivating lentiviral vector for SCID-X1 gene therapy that does not activate LMO2 expression in human T cells. Blood (2010) 116:900-8. doi: 10.1182/blood2009-10-250209

107. Santilli G, Thornhill SI, Kinnon C, Thrasher AJ. Gene therapy of inherited immunodeficiencies. Expert Opin Biol Ther (2008) 8:397-407. doi: 10.1517/ 14712598.8.4.397

108. Naldini L, Blömer U, Gallay P, Ory D, Mulligan R, Gage FH, et al. In vivo gene delivery and stable transduction of nondividing cells by a lentiviral vector. Science (1996) 272:263-7. doi: 10.1126/science.272.5259.263

109. Aiuti A, Biasco L, Scaramuzza S, Ferrua F, Cicalese MP, Baricordi C, et al. Lentiviral hematopoietic stem cell gene therapy in patients with Wiskott-Aldrich syndrome. Science (2013) 341:1233151. doi: 10.1126/science.1233151

110. Biffi A, Montini E, Lorioli L, Cesani M, Fumagalli F, Plati T, et al. Lentiviral hematopoietic stem cell gene therapy benefits metachromatic leukodystrophy. Science (2013) 341:1233158. doi: 10.1126/science. 1233158

111. Poletti V, Charrier S, Corre G, Gjata B, Vignaud A, Zhang F, et al. Preclinical Development of a Lentiviral Vector for Gene Therapy of X-Linked Severe Combined Immunodeficiency. Mol Ther Methods Clin Dev (2018) 9:257-69. doi: 10.1016/j.omtm.2018.03.002

112. Huston MW, van Til NP, Visser TP, Arshad S, Brugman MH, Cattoglio C, et al. Correction of murine SCID-X1 by lentiviral gene therapy using a codon-optimized IL2RG gene and minimal pretransplant conditioning. Mol Ther (2011) 19:1867-77. doi: 10.1038/mt.2011.127

113. Candotti F, Shaw KL, Muul L, Carbonaro D, Sokolic R, Choi C, et al. Gene therapy for adenosine deaminase-deficient severe combined immune deficiency: clinical comparison of retroviral vectors and treatment plans. Blood (2012) 120:3635-46. doi: 10.1182/blood-2012-02-400937

114. Ginn SL, Curtin JA, Kramer B, Smyth CM, Wong M, Kakakios A, et al. Treatment of an infant with X-linked severe combined immunodeficiency (SCID-X1) by gene therapy in Australia. Med J Aust (2005) 182:458-63. doi: 10.5694/j.1326-5377.2005.tb06785.x

115. Izotova N, Rivat C, Baricordi C, Pellin D, Adams S, Gkazi AS, et al. Production of Genetically Engineered T and NK Cells is Maintained in Humans by Common Long Term Lymphoid Progenitors 15 Years after Loss of Transplanted Hematopoietic Stem Cells. Complete list of abstracts for the 23rd Annual Meeting of the American Society for Gene and Cell Therapy. 2020 May 12-15; Virtual meeting. Mol Ther (2020) 28:406. doi: 10.1016/ j.ymthe.2020.04.019. Elsevier.

116. Cavazzana M, Ribeil J-A, Lagresle-Peyrou C, André-Schmutz I. Gene Therapy with Hematopoietic Stem Cells: The Diseased Bone Marrow's Point of View. Stem Cells Dev (2017) 26:71-6. doi: 10.1089/scd.2016.0230

117. Hassan A, Lee P, Maggina P, Xu JH, Moreira D, Slatter M, et al. Host natural killer immunity is a key indicator of permissiveness for donor cell engraftment in patients with severe combined immunodeficiency. J Allergy Clin Immunol (2014) 133:1660-6. doi: 10.1016/j.jaci.2014.02.042

118. Clarke EL, Connell AJ, Six E, Kadry NA, Abbas AA, Hwang Y, et al. T cell dynamics and response of the microbiota after gene therapy to treat $\mathrm{X}$-linked severe combined immunodeficiency. Genome Med (2018) 10:70. doi: 10.1186/s13073-018-0580-z

119. Scala S, Basso-Ricci L, Dionisio F, Pellin D, Giannelli S, Salerio FA, et al. Dynamics of genetically engineered hematopoietic stem and progenitor cells after autologous transplantation in humans. Nat Med (2018) 24:1683-90. doi: 10.1038/s41591-018-0195-3

120. Blanco E, Pérez-Andrés M, Arriba-Méndez S, Contreras-Sanfeliciano T, Criado I, Pelak O, et al. Age-associated distribution of normal B-cell and plasma cell subsets in peripheral blood. J Allergy Clin Immunol (2018) 141:2208-19. doi: 10.1016/j.jaci.2018.02.017

121. Manz RA, Hauser AE, Hiepe F, Radbruch A. Maintenance of serum antibody levels. Annu Rev Immunol (2005) 23:367-86. doi: 10.1146/ annurev.immunol.23.021704.115723

122. Tarlinton D, Radbruch A, Hiepe F, Dorner T. Plasma cell differentiation and survival. Curr Opin Immunol (2008) 20:162-9. doi: 10.1016/j.coi.2008.03.016

123. Perez-Andres M, Paiva B, Nieto WG, Caraux A, Schmitz A, Almeida J, et al. Human peripheral blood B-cell compartments: a crossroad in B-cell traffic.
Cytometry B Clin Cytom (2010) 78 Suppl 1:S47-60. doi: 10.1002/ cyto.b. 20547

124. Heimall J, Buckley RH, Puck J, Fleisher TA, Gennery AR, Haddad E, et al. Recommendations for Screening and Management of Late Effects in Patients with Severe Combined Immunodeficiency after Allogenic Hematopoietic Cell Transplantation: A Consensus Statement from the Second Pediatric Blood and Marrow Transplant Consortium Inter. Biol Blood Marrow Transplant (2017) 23:1229-40. doi: 10.1016/j.bbmt.2017.04.026

125. Desjardins M. Mazer BD. B-cell memory and primary immune deficiencies: interleukin-21 related defects. Curr Opin Allergy Clin Immunol (2013) 13:639-45. doi: 10.1097/ACI.0000000000000009

126. Taylor N, Candotti F, Smith S, Oakes SA, Jahn T, Isakov J, et al. Interleukin-4 signaling in B lymphocytes from patients with X-linked severe combined immunodeficiency. J Biol Chem (1997) 272:7314-9. doi: $10.1074 /$ jbc. 272.11 .7314

127. Touzot F, Moshous D, Creidy R, Neven B, Frange P, Cros G, et al. Faster Tcell development following gene therapy compared with haploidentical HSCT in the treatment of SCID-X1. Blood (2015) 125:3563-9. doi: 10.1182/blood-2014-12-616003

128. Laffort C, Le Deist F, Favre M, Caillat-Zucman S, Radford-Weiss I, Debre M, et al. Severe cutaneous papillomavirus disease after haemopoietic stem-cell transplantation in patients with severe combined immune deficiency caused by common gammac cytokine receptor subunit or JAK-3 deficiency. Lancet (London England) (2004) 363:2051-4. doi: 10.1016/S0140-6736(04)16457-X

129. Vely F, Barlogis V, Vallentin B, Neven B, Piperoglou C, Ebbo M, et al. Evidence of innate lymphoid cell redundancy in humans. Nat Immunol (2016) 17:1291-9. doi: 10.1038/ni.3553

130. Vivier E, Vely F, Fischer A. Reply to "Comment on: Evidence of innate lymphoid cell redundancy in humans”. Nat Immunol (2018) 19:789-90. doi: 10.1038/s41590-018-0165-4

131. Orange JS, Mace EM, French AR, Yokoyama WM, Fehniger TA, Cooper MA. Comment on: Evidence of innate lymphoid cell redundancy in humans. Nat Immunol (2018) 19:788-9. doi: 10.1038/s41590-018-0164-5

132. Kohn DB. Gene therapy outpaces haplo for SCID-X1. Blood (2015) 125:3521-2. doi: 10.1182/blood-2015-04-641720

133. Schott JW, León-Rico D, Ferreira CB, Buckland KF, Santilli G, Armant MA, et al. Enhancing Lentiviral and Alpharetroviral Transduction of Human Hematopoietic Stem Cells for Clinical Application. Mol Ther Methods Clin Dev (2019) 14:134-47. doi: 10.1016/j.omtm.2019.05.015

134. Bauler M, Roberts JK, Wu C-C, Fan B, Ferrara F, Yip BH, et al. Production of Lentiviral Vectors Using Suspension Cells Grown in Serum-free Media. Mol Ther Methods Clin Dev (2020) 17:58-68. doi: 10.1016/j.omtm.2019.11.011

135. Bernadin O, Amirache F, Girard-Gagnepain A, Moirangthem RD, Lévy C, Ma K, et al. Baboon envelope LVs efficiently transduced human adult, fetal, and progenitor T cells and corrected SCID-X1 T-cell deficiency. Blood Adv (2019) 3:461-75. doi: 10.1182/bloodadvances.2018027508

136. Genovese P, Schiroli G, Escobar G, Di Tomaso T, Firrito C, Calabria A, et al. Targeted genome editing in human repopulating haematopoietic stem cells. Nature (2014) 510:235-40. doi: 10.1038/nature13420

137. Schiroli G, Ferrari S, Conway A, Jacob A, Capo V, Albano L, et al. Preclinical modeling highlights the therapeutic potential of hematopoietic stem cell gene editing for correction of SCID-X1. Sci Transl Med (2017) 9:eaan0820. doi: $10.1126 /$ scitranslmed.aan0820

138. Menon T, Firth AL, Scripture-Adams DD, Galic Z, Qualls SJ, Gilmore WB, et al. Lymphoid regeneration from gene-corrected SCID-X1 subject-derived iPSCs. Cell Stem Cell (2015) 16:367-72. doi: 10.1016/j.stem.2015.02.005

139. Pavel-Dinu M, Wiebking V, Dejene BT, Srifa W, Mantri S, Nicolas CE, et al. Gene correction for SCID-X1 in long-term hematopoietic stem cells. Nat Commun (2019) 10:1634. doi: 10.1038/s41467-019-09614-y

140. Hiramoto T, Li LB, Funk SE, Hirata RK, Russell DW. Nuclease-free AdenoAssociated Virus-Mediated Il2rg Gene Editing in X-SCID Mice. Mol Ther (2018) 26:1255-65. doi: 10.1016/j.ymthe.2018.02.028

141. Booth C, Romano R, Roncarolo MG, Thrasher AJ. Gene therapy for primary immunodeficiency. Hum Mol Genet (2019) 28:R15-23. doi: 10.1093/hmg/ ddz170

142. Zhang Z-Y, Thrasher AJ, Zhang F. Gene therapy and genome editing for primary immunodeficiency diseases. Genes Dis (2020) 7:38-51. doi: 10.1016/ j.gendis.2019.07.007 
143. Rai R, Thrasher AJ, Cavazza A. Gene Editing for the Treatment of Primary Immunodeficiency Diseases. Hum Gene Ther (2020) (in press). doi: 10.1089/ hum.2020.185

144. Rajawat YS, Humbert O, Kiem H-P. In-Vivo Gene Therapy with Foamy Virus Vectors. Viruses (2019) 11:1091. doi: 10.3390/v11121091

145. Humbert O, Chan F, Rajawat YS, Torgerson TR, Burtner CR, Hubbard NW, et al. Rapid immune reconstitution of SCID-X1 canines after G-CSF/ AMD3100 mobilization and in vivo gene therapy. Blood Adv (2018) 2:987-99. doi: 10.1182/bloodadvances.2018016451

146. Burtner CR, Beard BC, Kennedy DR, Wohlfahrt ME, Adair JE, Trobridge $\mathrm{GD}$, et al. Intravenous injection of a foamy virus vector to correct canine SCID-X1. Blood (2014) 123:3578-84. doi: 10.1182/blood-2013-11-538926
Conflict of Interest: AT is a co-founder and consultant to Orchard Therapeutics.

The remaining authors declare that the research was conducted in the absence of any commercial or financial relationships that could be construed as a potential conflict of interest.

Copyright () 2020 Blanco, Izotova, Booth and Thrasher. This is an open-access article distributed under the terms of the Creative Commons Attribution License (CC BY).

The use, distribution or reproduction in other forums is permitted, provided the original author(s) and the copyright owner(s) are credited and that the original publication in this journal is cited, in accordance with accepted academic practice. No use, distribution or reproduction is permitted which does not comply with these terms. 